\title{
A Basic Method for Naming Persian Karbandis Using a Set of Numbers
}

\author{
Mojtaba Pour Ahmadi
}

Published online: 6 June 2014

(C) Kim Williams Books, Turin 2014

\begin{abstract}
Identifying and recognizing the name of a karbandi especially when visiting real examples in buildings is a difficult job to do using current traditional methods. This paper sets out to introduce a new standard method for naming karbandis according to their main geometrical characteristics. The new standard uses a combination of numbers for this purpose. In this paper, after reviewing and analyzing three main sources on naming Persian karbandis, the new approach is introduced and its application is explained through some examples.
\end{abstract}

Keywords Karbandi - Traditional architecture · Iran · Design analysis · Pirnia · Sha'rbaf · Lorzadeh · Ribbed vault

\section{Introduction}

During site visits with students to historic Persian architectural works, it was apparent that most of these students were not willing to engage with karbandis in historical constructions. Their general impression was that karbandis were too complicated to be worth examining and that it would take a lot of time and energy from them to learn about karbandis and their principles and rules.

In a close examination one may accept that the students are to some extent right about karbandis. The available resources for learning about Persian karbandis have some characteristics that make them difficult to use for ordinary readers. The language used in these resources gives the impression of being old-fashioned, complicated and relatively detached from today's academic language. In addition, it

\footnotetext{
M. Pour Ahmadi $(\bowtie)$

Department of Architecture, Faculty of Architecture and Arts, University of Guilan, Rasht, Guilan, Iran

e-mail: mojtaba.pourahmadi@yahoo.com
} 
is observed that there are some ambiguities or discrepancies in traditional definitions and methods that add to the difficulty of the job.

Considering these difficulties, this paper asks the question: "how can a new interpretation of karbandis be presented to today's academic audience which is more user-friendly?" This is a broad problem that consists of a lot of sub-problems and depends on a lot of factors. This paper aims to solve part of this general problem.

The problem that is examined in this paper is how one can classify and name a Persian karbandi especially when one is on a site visit. The author's hypothesis is that adoption of a pure geometrical point of view towards karbandis can be an effective approach to solve this problem. Therefore, this paper tries to introduce a new geometrical approach towards naming karbandis that is simple to use, standard, and free from the difficulties of similar traditional methods. This way, students of architecture may be able to better communicate with the concept of karbandi and work on it.

In this paper, first a literature review is conducted to recognize important features of karbandis from the viewpoint of traditional Iranian architects and to categorize the methods used to identify karbandis. After recognizing existing difficulties, the author suggests that instead of using the traditional methods, a new pure geometrical approach be adopted to classify karbandis and a set of numbers be used to name every karbandi. Finally, this new method is introduced and explained.

\section{What is Karbandi?}

A definition for karbandi as a component of Persian architecture is as follows:

Karbandi is the structure of a kind of roofing, consisting of ribs with a certain arched form which interlock according to certain geometrical rules and form the main frame of the roof. (Bozorgmehri 1992: 1).

After erecting the ribs on the base pillars, builders could fill in the empty spaces between the interlaced ribs (the webs) by masonry materials. By using ordered geometrical patterns to set up the ribs, the resulting structure performed an ornamental role too. This way, karbandi played a significant role in Persian architecture both structurally and aesthetically (Fig. 1). ${ }^{1}$

Generally we know that the history of karbandi in Persian architecture is long. It seems that karbandi can be classified as a component of ribbed vaults. ${ }^{2}$ It is known that from about the tenth century on, ribbed vaults were used in both the Islamic and Christian world (Fuentes and Huerta 2010).

\section{Literature on Traditional Methods of Naming Karbandis}

Although there was a widespread use and a rich variety of karbandis in Persian architecture during its long history, unfortunately, the existing literature on this

\footnotetext{
${ }^{1}$ It should be mentioned that the karbandi was not always used as the main load-bearing structure of the roofing system. Sometimes they are just superficial coverings for the main load-bearing structures of the roof.

${ }^{2}$ However, conclusive statement on this issue needs more investigation.
} 


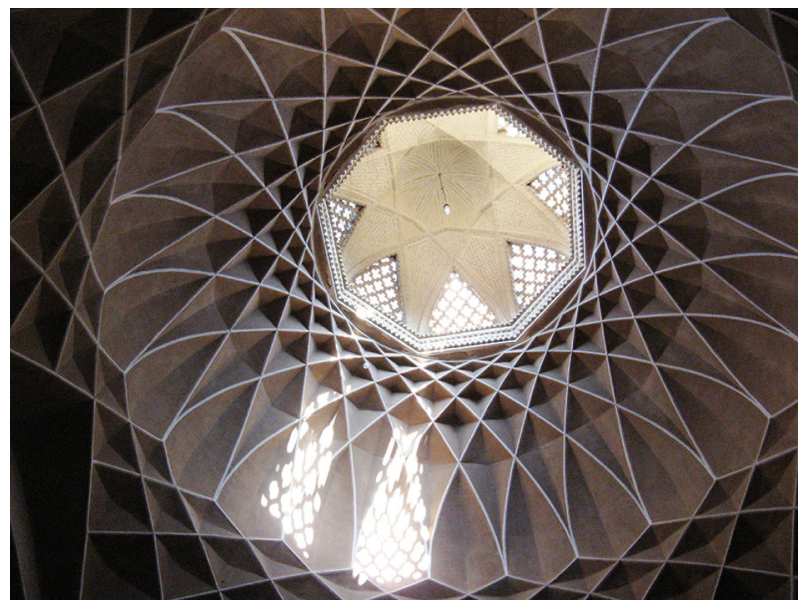

Fig. 1 Karbandi in the pavilion of the Doulat Abad garden, Yazd, Iran, 18th century

subject is limited. One of the difficulties arising from this condition is that our knowledge of the methods that Persian masons and architects used to identify, name and design different karbandis is in small supply.

During recent decades some books have been written about karbandis. As far as the author has searched, today there are four main books that refer to the identification and designing of karbandis in Persian architecture narrating directly from Iranian traditional architects. These books discuss the karbandis from the viewpoints of three of traditional architects.

The first book is written by Mrs. Bozorgmehri first published in 1981. As mentioned within the preface of the book (Bozorgmehri 1992), this work was based on the teachings of Master Pirniā who was an important commentator on the traditional architecture of Iran. He was from Yazd city and it can be said that his knowledge of Persian architecture is mainly tinged with his attitude towards the architecture of Yazd and the central plateau of Iran.

The second and third important books are written by Master Sha'rbāf and one of his trainees first published in 1982 and 1999 (see Sha'rbaf 2006; Pour Nāderi 1999). The last important book is based on the teachings of Master Lorzādeh written by two of his trainees first published in 1995 (Ra'ees Zadeh and Mofid 2011). These masters both lived in Tehran and their knowledge of architecture was mainly influenced by the architecture of this city.

In this paper, we will review these four books and analyze their approaches to naming karbandis. These are the books that are referred to mostly in Iran's academic environments and students use them as reference books. In addition, with regard to the problem examined in this paper, they provide the necessary insight towards Persian karbandi, therefore the author does not go after older historical literature in order to probably find some other sources or approaches. After this we refer to the contents of these books as the 


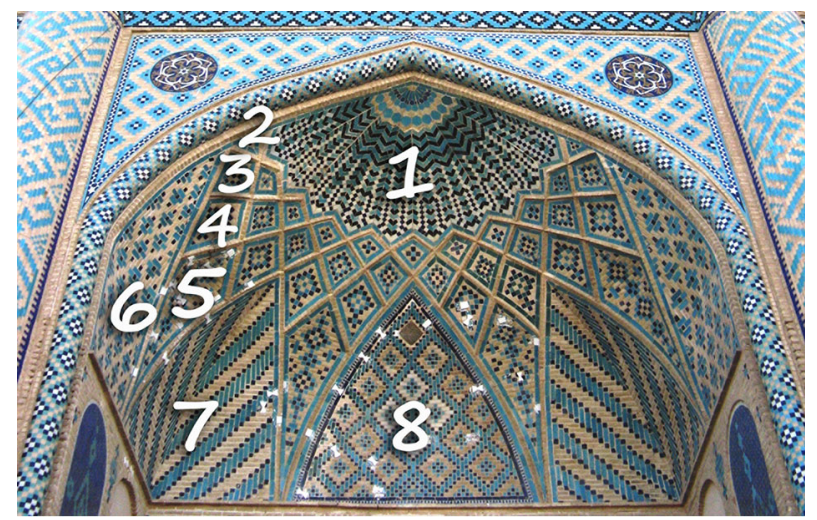

\begin{tabular}{|l|l|l|l|}
\hline $\begin{array}{l}\text { Cell } \\
\text { no. }\end{array}$ & Persian Name & $\begin{array}{l}\text { Original definition of } \\
\text { Persian names }\end{array}$ & $\begin{array}{l}\text { English } \\
\text { translation/transliteration }\end{array}$ \\
\hline 1 & Shamseh & Having a shape like the sun & Shamseh \\
\hline $2,3,4$ & Toranj & Citron, Etrog Citron & Toranj \\
\hline 5 & Pā-bārik & Having a thin foot & Thin-footed \\
\hline 6 & $\begin{array}{l}\text { Nim-soosani/ } \\
\text { Soosan/Soosani }\end{array}$ & $\begin{array}{l}\text { Half of a Lily-like cell/ lily/ } \\
\text { Liliaceous }\end{array}$ & Soosan \\
\hline 8 & Soosan/Soosani & Lily/ Liliaceous & Soosan \\
\hline 7 & Filgoosh/ Haft/Hafti & $\begin{array}{l}\text { (Like the) Ear of an elephant/ } \\
\text { seven/ like a seven }\end{array}$ & Squinch \\
\hline
\end{tabular}

Fig. 2 Main cells forming a karbandi. This karbandi is called a nim-kār (Semi-work). Amir Chakhmāgh complex, Yazd, from 15th century

viewpoints and opinions of Master Pirniā, Master Sha'rbāf, and Master Lorzādeh respectively.

\section{Naming Karbandis According to Traditional Methods}

Before examining the traditional methods for naming karbandis, it is necessary to become familiar with the names of different parts of a karbandi. These parts are called "ālat" in Farsi which is translated here as "cell". A karbandi is comprised of a number of different cells each of which has its specific name. In Fig. 2 the main cells of a karbandi are introduced. ${ }^{3}$

\footnotetext{
${ }^{3}$ Concerning the approach taken in translating the Persian terms into English a point should be mentioned. There may be some elements in Persian karbandi that have similar counterparts in European architecture that have a specific name in English. In these cases, the relevant English word is used to name that element of karbandi. For example, "rib" is used for "tavizeh" and "squinch" for "filgoosh". But in most cases the elements or characteristics of Persian karbandi as they were defined by Persian architects, do not have any counterpart in English architecture i.e., the European architects did not use technical words to name them. Therefore, there is not a specific word in English that can be simply used in translation. Here, as far as the author knows, three main approaches can be taken: First, transliteration i.e., to use the exact Persian term in English and not change it at all, as is the case for the very term "karbandi". Second, to translate literally the Persian terms into English; for instance, to use the word
} 
Table 1 Terminology used by the three traditional architects for naming a karbandi

\begin{tabular}{|l|l|l|c|c|c|}
\hline No. & Characteristics and terms & \multicolumn{1}{|c|}{ In Farsi } & Pirniā & Sha'rbāf & Lorzādeh \\
\hline 1 & $\begin{array}{l}\text { plumb } \\
\text { / out of plumb }\end{array}$ & $\begin{array}{l}\text { GhālebShāghooli } \\
\text { / GhālebSarSeft }\end{array}$ & & \\
\hline 2 & Number of sides & Azla' & & \\
\hline 3 & Conventional / Stellar & Rasmi/ Akhtari & & & \\
\hline 4 & Outline of the base & Zamineh & & & \\
\hline 5 & Extension & Gostaresh & & & \\
\hline 6 & Repetition & Parvar & & \\
\hline 7 & Interlaced extension & $\begin{array}{l}\text { Gostaresh-e dar } \\
\text { ham }\end{array}$ & & & \\
\hline 8 & One-footed/ two -footed & Yek-pā/ Do-pā & & & \\
\hline 9 & Broken filter tip & $\begin{array}{l}\text { Moshtak- } \\
\text { shekasteh }\end{array}$ & & & \\
\hline 10 & End-reaching & Kuneh-bandi & & & \\
\hline 11 & With soosan & Soosan-dār & & \\
\hline 12 & With squinch & Filgoosh-dār & & & \\
\hline 13 & Square nimkār & Nimkār-e morabba' & & & \\
\hline 14 & Deep nimkār & Nimkār-e noghol & & & \\
\hline 15 & Shallow nimkār & Nimkār-e tonok & & & \\
\hline 16 & Two-footed nimkār & Nimkār-e Do-pā & & \\
\hline
\end{tabular}

The hollow tick is used to indicate a difference in meaning or use

By studying the resources it becomes apparent that these three masters use different naming systems for karbandis. They notice different features of karbandis and use different terms to name a certain karbandi. In Table 1 characteristics that are used by these masters to name karbandis are listed. ${ }^{4}$

As it is observed in the table, each of the master architects uses a specific set of parameters to define a karbandi. Next we will review and explain the terms in brief:

\section{Footnote 3 continued}

"thin-footed" for "pa-barik". Third approach is by considering the Persian term and trying to find a higher level of abstraction or giving a kind of interpretation for it; then translating the abstracted definition or interpretation into English. This is the approach that is taken by for example professor Necipoglu when she names the cells of Persian girih works (1995). Through a geometrical interpretation, she uses "kite-shaped rhomboid" for "toranj" and "ten pointed composite polygon" for the "sorme-dān" cell which means "kohl container" in Farsi (Ibid). In this paper the third approach could not be suitable, since the main claim of the research is that the original system of naming karbandis has difficulties and needs to be upgraded and redefined in today's language. Therefore, it seems reasonable to use the original terms or their literal translation when the paper is describing the difficulties of traditional methods.

4 For more information about the translation of the terms, see "Appendix". 

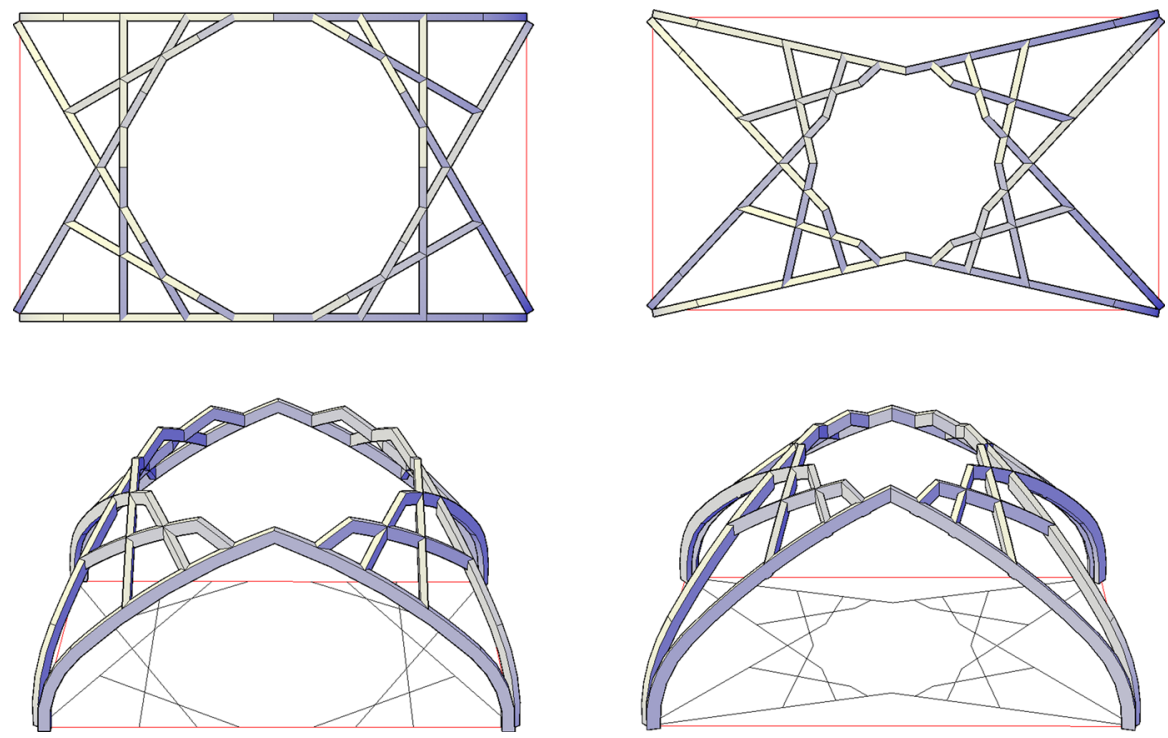

Fig. 3 An example of a plumb karbandi in the left and an out of plumb karbandi in the right

\section{Plumb/Out of Plumb}

If the slight differences between Pirnia and Sharbaf's attitudes regarding this issue are ignored, it can be said generally that if each pair of ribs (a Tavizeh, in Farsi) are erected in a way that their two starting points (springs), and crown are located in a vertical flat surface then the resulting karbandi is a plumb kind, otherwise it will be an out of plumb one (Bozorgmehri 1992: 11; Sha'rbaf 2006: 9-10).

In the out of plumb kind, the designer can decrease the size of the shamseh. The load-bearing capacity of this kind of karbandis is less than that of the plumb kind (Fig. 3). Surprisingly, the two masters sometimes call a karbandi with actually out of plumb formwork, a plumb karbandi. ${ }^{5}$

\section{Number of Sides}

This attribute is the most common parameter for identifying karbandis. It refers to the number of segments used to design the karbandi and it can be recognized most easily by looking at the shamseh of a karbandi. If the shamseh's horizontal plan is a regular polygon, the number of its sides determines the name of the karbandi and if its plan is a star polygon, the number of its wings specifies that (Fig. 4).

\footnotetext{
5 Pirnia explains this condition in this way: that the butterfly cells (Shaparaki, in Farsi) adjacent to the Shamseh are omitted (Bozorgmehri 1992: 40). So, he disregards the fact that the ribs are not self-stable any longer and the karbandi must be called out of plumb according to his own definition. Therefore, it seems that in reality the method of drawing the ribs and the size of the Shamseh of a karbandi is more important a factor in defining which kind it is. But the traditional masters do not explain it in this way.
} 


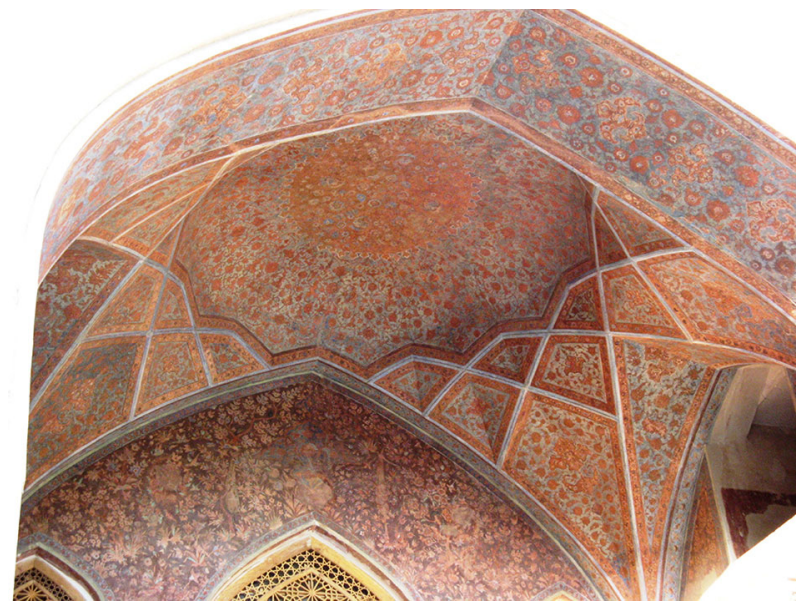

Fig. 4 An example of a 12-sided karbandi. Chehel-Sotun palace, Isfahan, 17th century

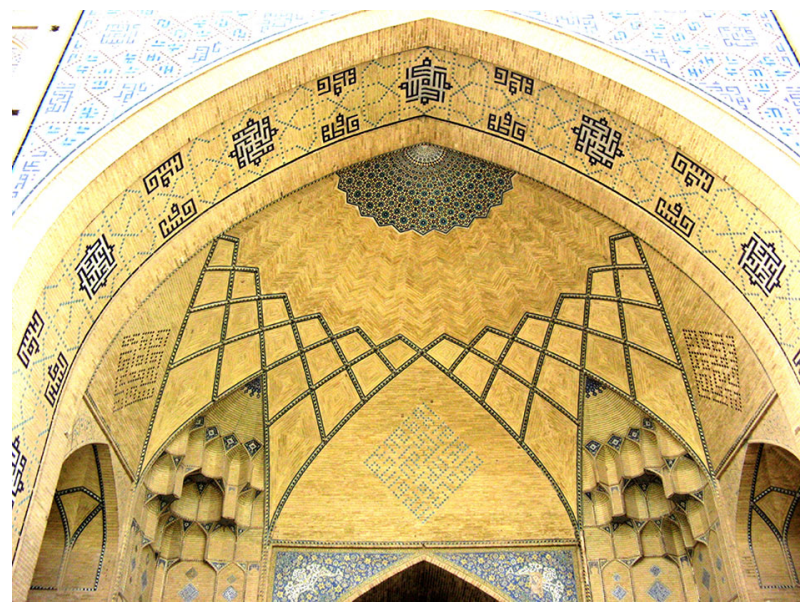

Fig. 5 An example of a 24-sided karbandi. In nimkars (semi-works) like this the sides of full shamseh are counted. In this case a muqarnas vault is executed in each squinch. Hakim mosque, Isfahan, 17th century

It should be mentioned that the shape of the full shamseh is considered to determine the number of its sides e.g., in iwans in which the shamseh is half-shaped the completed shape of the shamseh should be the basis for counting (Fig. 5).

\section{Conventional/Stellar}

Pirnia divides plumb karbandis into two groups based on how the points on the circumferential circle are connected to each other by line segments (Bozorgmehri 1992: 12). 
First, the conventional (rasmi, in Farsi) one: the longer side of the base rectangle is set as the basis and it is considered how many segments of the circumferential circle are located between the two end points of this longer side. Then each point on the circumferential circle is connected to other points that have the same distance from it. This way a conventional karbandi is formed (Bozorgmehri 1992: 12-13).

Second, the stellar (akhtari, in Farsi) one: if in connecting the points on the circumferential circle the above mentioned basis is not regarded and the points are connected with a fixed larger distance, the resulting karbandi will be a stellar one. Then one should mention the number of segments of this distance in naming the karbandi. Pirnia mentions this distance as for example "six to six" or "seven to seven" and so on in naming these karbandis (Fig. 6). According to Pirnia, stellar karbandis are divided into continuous and discrete ones. (Bozorgmehri 1992: 14-15).
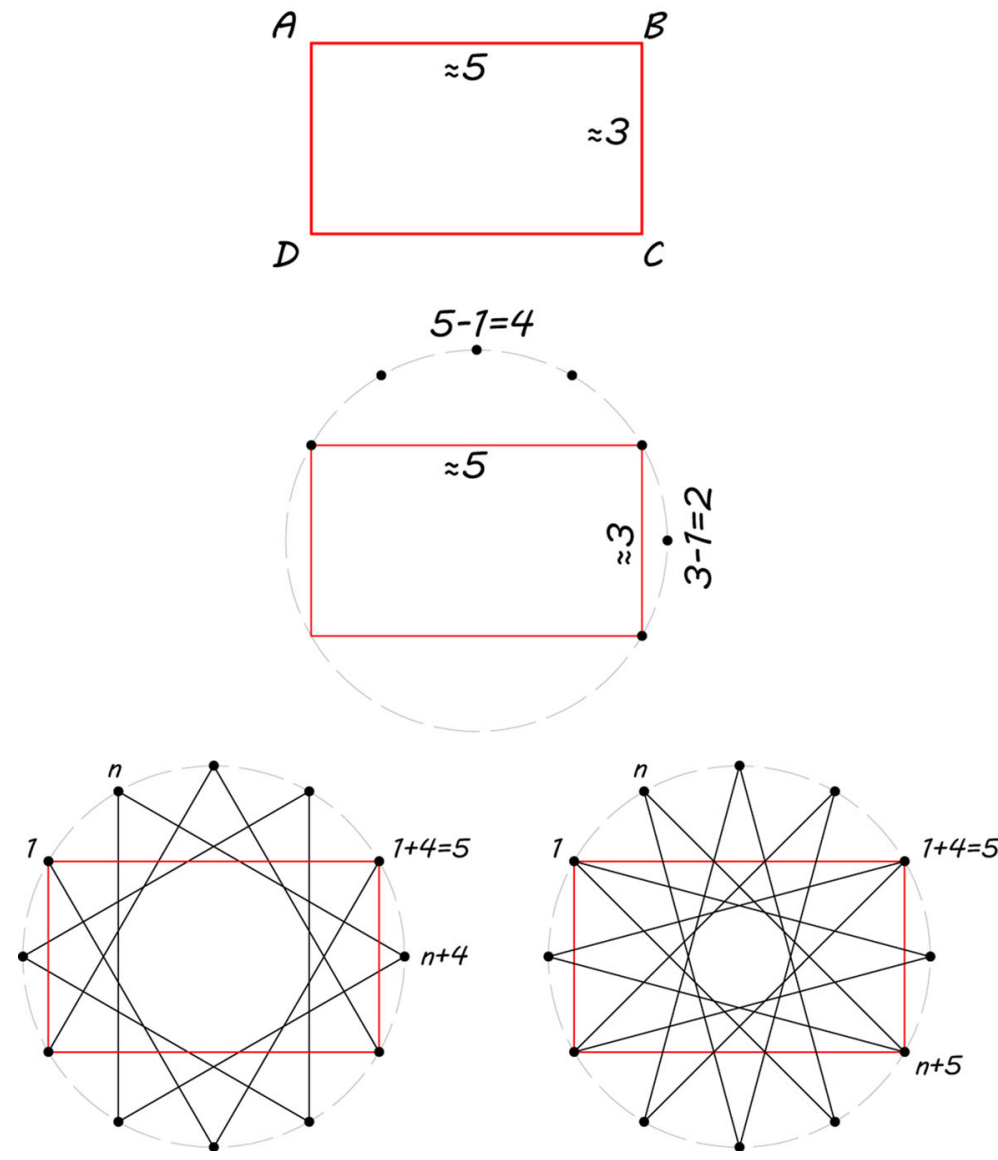

Fig. 6 An example of a conventional karbandi in the lower left and a stellar karbandi in the lower right, according to Pirnia's method 

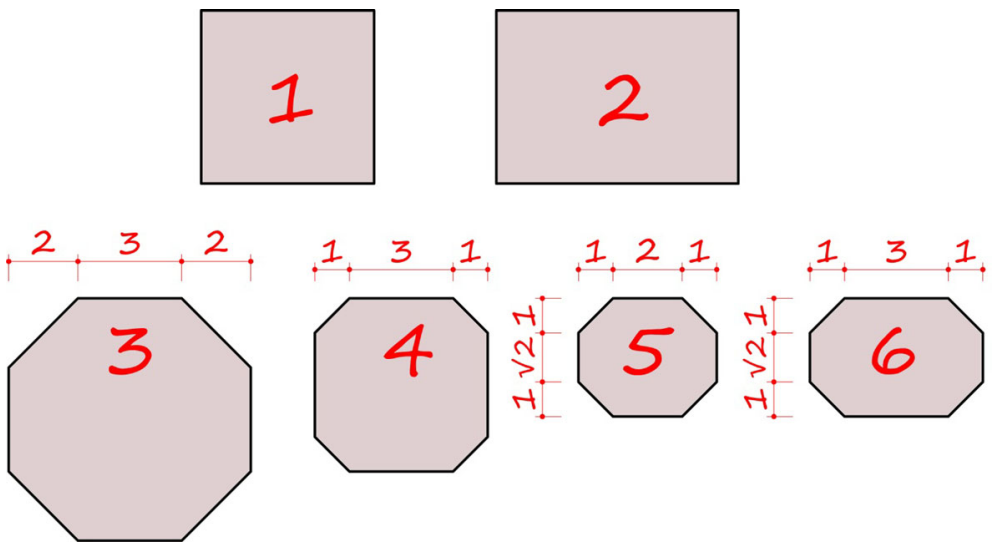

Fig. 7 Some bases for karbandis according to Pirnia (Bozorgmehri 1992: 16): 1 square; 2 rectangle; 3 hasht (eight); 4 hasht va nim-hasht (eight and half-eight); 5 negini (ring-stone-like); 6 kashkooli (like the bowl of dervishes)

Outline of the Base

Except in Lorzadeh's book, in which the name of the base for karbandi is used very limitedly, both other masters use a variety of traditional terms to describe the base outline of the karbandi e.g., square, rectangle, hasht (eight), Negini (ring-stone-like) (Bozorgmehri 1992; Pour Naderi 1999; Sha'rbaf 2006) (see Fig. 7).

\section{Extension}

Only Pirnia uses this feature to name karbandis. He considers some karbandis as the extended form of some basic karbandis (Bozorgmehri 1992).

\section{Repetition}

Sometimes in long narrow bases, the designer had the possibility to design a full karbandi in the center and two half-karbandis of the same type on its sides. Pirnia calls the resulting vault a repetition (parvar, in Farsi) of the central karbandi (Bozorgmehri 1992).

\section{Interlaced Extension}

It seems that if a karbandi has an apparent cross-shaped composition, Pirnia regards it as two interlaced (dar-ham, in Farsi) extended types of a basic karbandi (Bozorgmehri 1992).

\section{One-Footed/Two-Footed}

Although Sharbaf does not present a clear definition for it, it can be inferred from his books that if thin-footed cells of a karbandi are so located that each one of them sits exactly on each corner of the base rectangle, the resulting karbandi is called a one-footed karbandi (Fig. 3) and if these cells are so located that two of them sit 

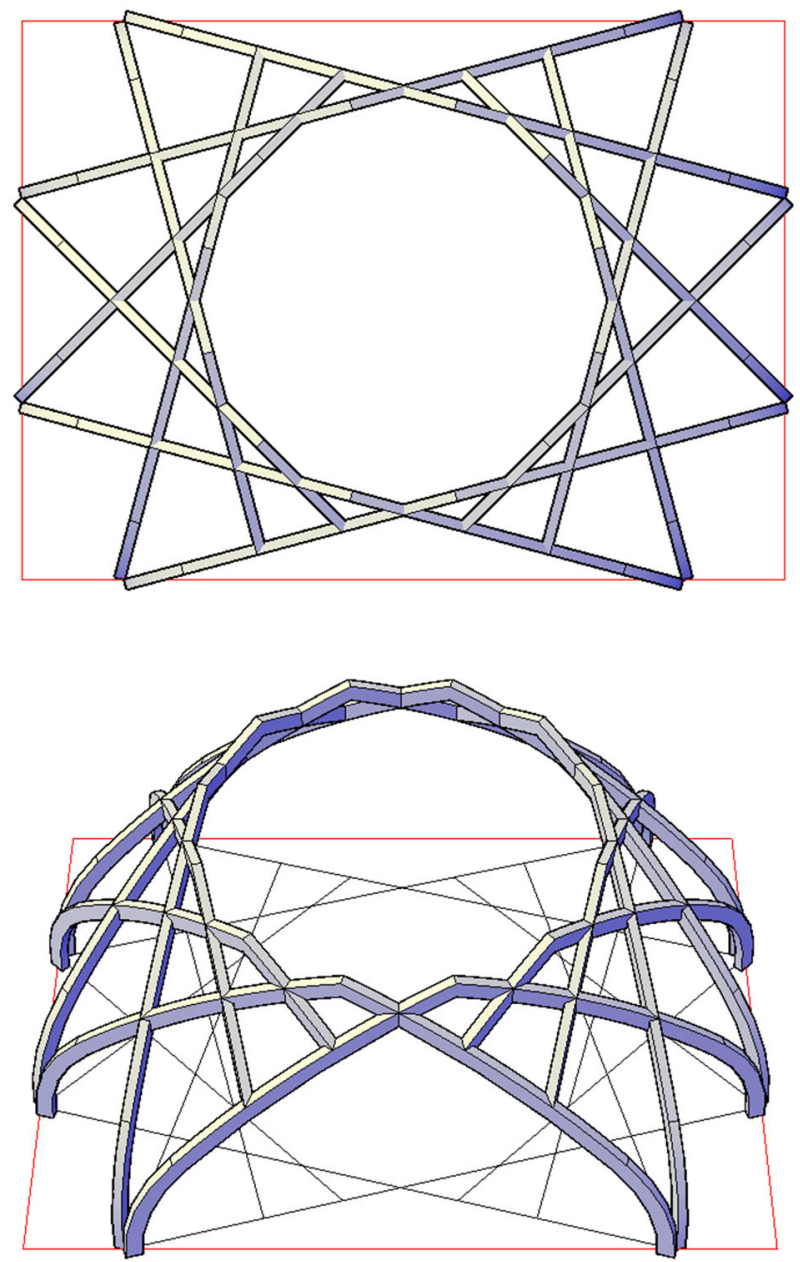

Fig. 8 A two-footed karbandi. Karbandis in Fig. 3 are one-footed

beside each corner of the base rectangle, it is a two-footed karbandi (Pour Naderi 1999; Sha'rbaf 2006) (Fig. 8).

In Pirnia's method usually no need is felt to mention this feature because when the shape of the base is exactly stated it usually, but not always, implies that the karbandi is one-footed or two-footed.

Surprisingly, there is a discrepancy between Lorzadeh's definition and Sharbaf's definition of this quality. In some cases what is called a one-footed karbandi in Sharbaf's method is called two-footed by Lorzadeh (see Table 1, item no. 16).

\section{Broken Filter Tip}

A karbandi which is constructed on an iwan, mehrāb, etc. is called a nimkār (semiwork) because it produces just a half of the complete vault and the front of the vault 


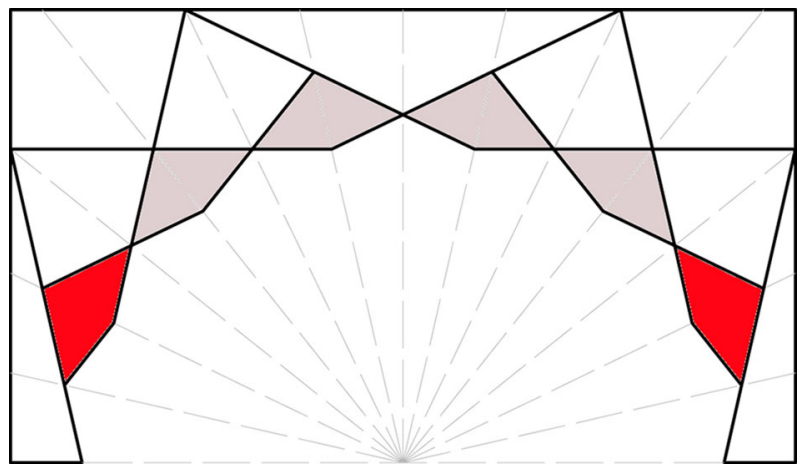

Fig. 9 An example of a broken filter tip karbandi

is open. In a nimkār, two toranjs that are located in the far most outer sides of the karbandi can have two states towards the edge of the iwan. If the toranj is leaning against the arch at the edge of the iwan, Sharbaf does not name it a certain name. But if the toranj is not leaning against the edge and has a distance from it, he calls this karbandi a broken filter tip (moshtak-shekasteh, in Farsi) (!) (Sha'rbaf 2006: 88) (Fig. 9).

\section{End-Reaching}

Sharbaf does not define it explicitly, but it seems that if the shamseh in a karbandi is at its largest possible size the karbandi is called end-reaching (kuneh bandi, in Farsi). That is to say in a square base the shamseh is tangent to all sides of the base and in a rectangular base it is tangent to the two longer sides (Sha'rbaf 2006: 120-123; Pour Naderi 1999: 160-161) (Fig. 10).

\section{With Soosan}

Lorzadeh's book is the most limited source on karbandis in comparison to the other two books. ${ }^{6}$ In Lorzadeh's method if the basic karbandi, which in fact is an endreaching karbandi in a square base in Sharbaf's naming system, is extended in one direction or in two opposite directions as far as a soosan (lily) cell is created, the resulting karbandi will be simply called a karbandi with soosan (Ra'ees Zādeh and Mofid 2011: 36) (Fig. 11).

\section{With Squinch}

In Lorzadeh's method if a basic karbandi is extended in three or four directions as far as two or four squinches are created at its corners, the resulting karbandi is called

\footnotetext{
${ }^{6}$ It should be acknowledged that these three masters' understanding of karbandis was certainly more than just what was written in these books. Their practice and prominent works testify to their expertise. But here we are just speaking about their books and what is written there.
} 
Fig. 10 An example of an endreaching karbandi, Akbariye mosque, Lahijan, Iran, 19th century
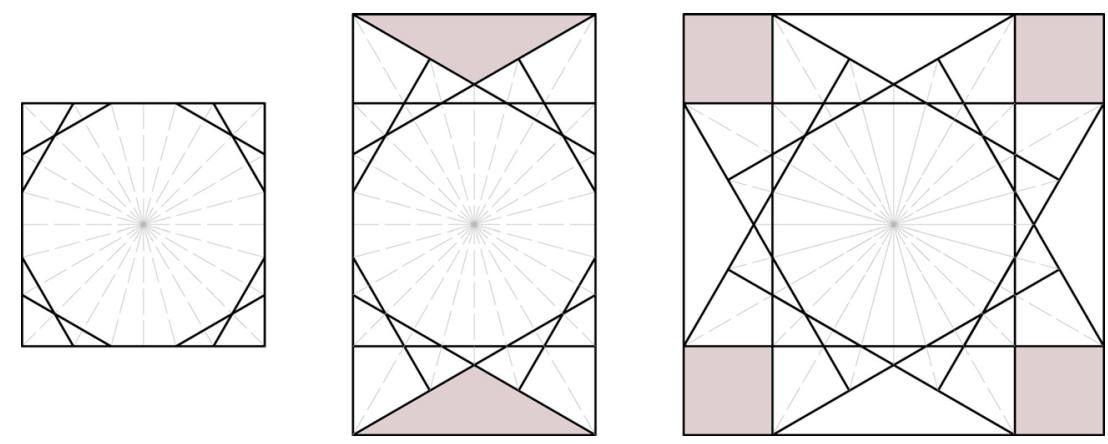

Fig. 11 Left a karbandi/rasmi of 12; centre: a rasmi of 12 with soosan (lily cells); right a rasmi of 12 with squinch cells. The soosans and the squinches are highlighted. Design of these karbandis is according to Lorzadeh's method

a karbandi with squinches (Ra'ees Zādeh and Mofid 2011: 37). It is clear that a karbandi that has squinches, has soosans too (Fig. 11).

Note that, a squinch is called a 'filgoosh' — which means elephant ear-by Lorzadeh, while it is called 'haft' or 'hafti'-which means 'seven'—in Sharbaf's terminology (Sha'rbaf 2006: 94). 


\section{Square Nimkār}

When explaining nimkār (semi-work) karbandis, Lorzādeh divides them into three groups. This division is derived from the ratio of the depth of the base to the front side (or span) of the base.

First group: if the depth is equal to the half length of the span, the karbandi is called a square nimkār (Ra'ees Zādeh and Mofid 2011: 38-40) (Fig. 12).

\section{Deep Nimkār}

The second group of nimkārs are deep (noghol, in Farsi) nimkārs. If the depth is larger than a half length of the span, the karbandi is called a deep nimkār in Lorzadeh's method (Ra'ees Zādeh and Mofid 2011: 40-41) (Fig. 13).

\section{Shallow Nimkār}

The third group of nimkārs are ones within which the depth of the base is smaller than a half length of the span. According to Lorzadeh these nimkārs can be of two kinds: first, shallow (tonok, in Farsi) nimkārs; second, two-footed nimkārs (Ra'ees Zādeh and Mofid 2011: 42).

A shallow nimkār has four thin-footed cells. On the sides of each corner there are two of them (Fig. 14).
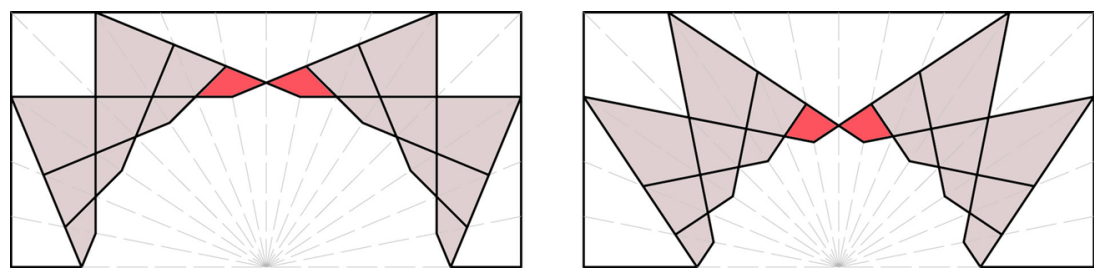

Fig. 12 A square nimkār of 16 perpendicularly drawn at the left side and a square nimkār of 16 with an optional-sized shamseh at the right as defined by Lorzadeh

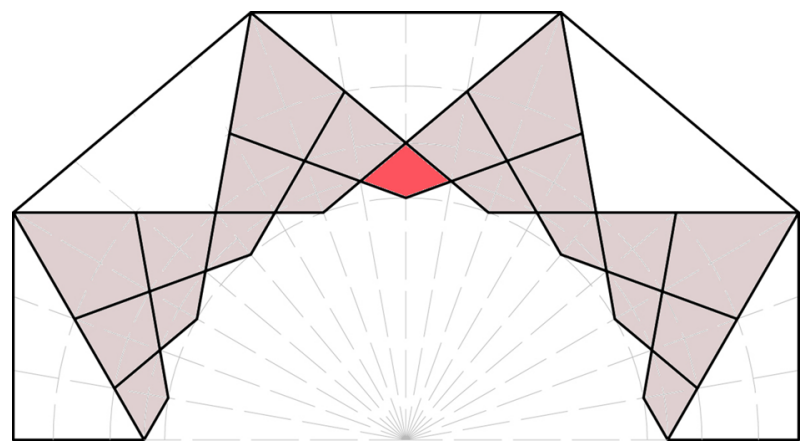

Fig. 13 An example of a deep nimkār 


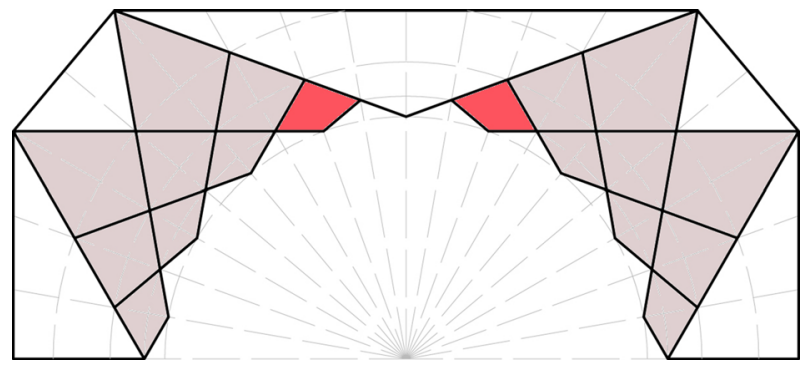

Fig. 14 An example of a shallow nimkār

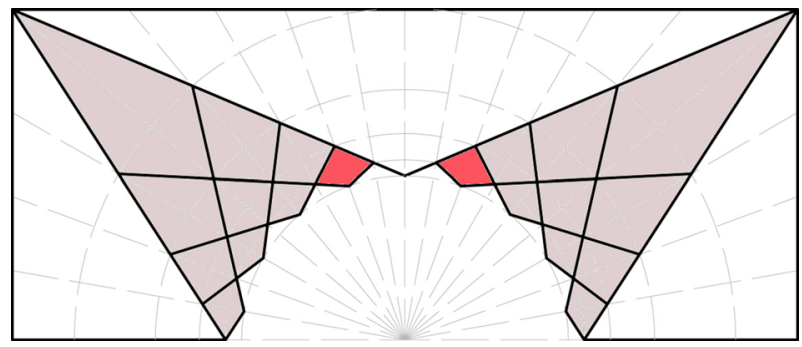

Fig. 15 An example of a two-footed nimkār according to Lorzadeh

\section{Two-Footed Nimkār}

According to Lorzade, within the third group of nimkārs, two-footed nimkārs are ones that have one thin-footed cell at each corner of the base rectangle (Ra'ees Zādeh and Mofid 2011: 42). This seems to be in contrast to what establishes a two-footed karbandi in Sharbaf's view, because this is what Sharbaf calls a one-footed karbandi (Fig. 15).

\section{The Need for a New Standard Method for Naming Karbandis}

By reviewing the literature, we can see that although these sources provide us with invaluable information about karbandis, there are some difficulties concerning the methods used by these master architects to name karbandis.

They usually lack a systematic approach to explain the terms, subjects, and methods. All three books have a case-based structure in which different karbandis are introduced one by one and do not try to organize the cases in a clear order. And because of their quality of being of few words, the reader of these books must usually deduce from the plans what is really meant by some titles. Furthermore, there are occasions where a lack of scientific rigor is observed. For example, in both Pirnia and Sharbaf's methods there is a discrepancy in titling some cases as plumb or out of plumb and they do not define this quality in a consistent way.

There is a great emphasis on memorizing technical terms. This approach makes the understanding of karbandis unattractive for today's audience, among them 
architecture students, and hinders their close relation with karbandis. However, the terms used to name karbandis belong to a past culture. Although it uses some nice terms that echo a traditional mind set and a close relation to nature, there is a need to update them.

The traditional approaches taken to name karbandis are deeply constructionoriented and technological limitations of the time have influenced the whole notion of karbandi. Today's architecture students and designers need not think of karbandis within all those constraints. They can define karbandis using a freer approach.

Therefore, the need for a standard method to name karbandis is noticeable. The author suggests that a pure geometrical approach be taken to define and classify karbandis in a more user-friendly and up-to-date manner.

\section{The New Geometrical Method to Classify Karbandis}

In this section the new geometrical method to name karbandis is introduced. First, a geometrical explanation of karbandis is presented. Then the new method is explained step by step.

\section{Karbandi from a Geometrical Point of View}

The most basic geometrical explanation of the plan of a karbandi is that designing a karbandi on a specified base is equal to superimposing a part of a suitable starpolygon on that base (Fig. 16).

In Fig. 17 some star-polygons are illustrated. Hereafter we call these star polygons "basic stars" e.g., a basic-star of six or eight. In order to cover a rectangular base, which was usually the case in traditional architecture, only a basic

Fig. 16 A simple definition of designing karbandi on a given base

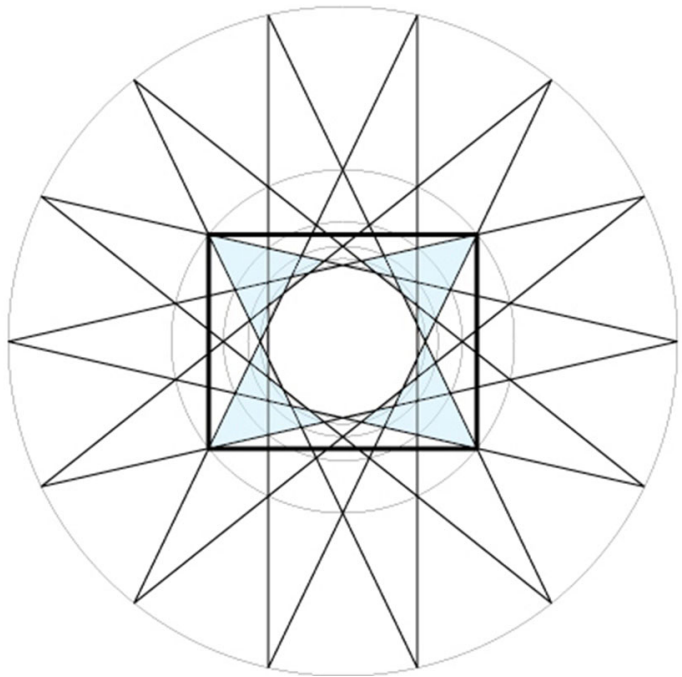



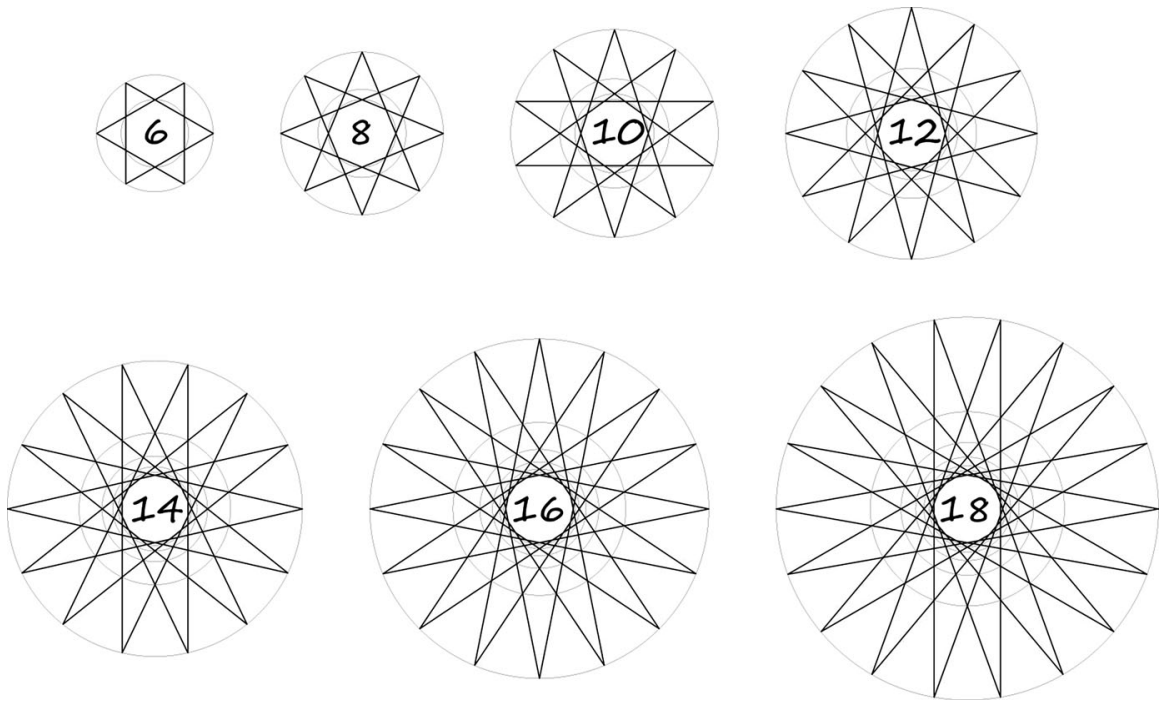

Fig. 17 Some basic stars for designing karbandi

star with an even number of wings could be used. Therefore, in Persian traditional architecture basic stars with even numbers of wings were the most used ones.

In every basic star a number of concentric circles can be defined (Fig. 17). Hereafter they will be called "circumferential circles". We will use these circles later to name karbandis.

The regular polygon or star-polygon that is formed at the center of a karbandi is the shamseh. Each line segment that connects two points of the largest circumferential circle represents a pair of ribs (tavizeh, in Farsi). Each pair of ribs can have the form of a straight line or a V-shaped line. If straight, it represents a plumb karbandi, otherwise an out of plumb one. In Persian architecture, if the karbandi is an out of plumb type, the size of the sun of it will be smaller than that of a similar plumb karbandi (Fig. 18).

Having a basic star at hand, one can design karbandis for a number of bases. To do that, one should connect the vertices on circumferential circles in a meaningful way. For example, with a basic star of fourteen and considering just full rectangular bases-leaving out nimkārs (semi-works) - the following set of bases may be covered with karbandi ${ }^{7}$ (Figs. 19, 20, 21, 22):

First, karbandis in which the four corners of the base rectangle sit on four vertices of a circumferential circle. The resulted karbandis, using the terminology of Sharbaf, are called one-footed karbandis (Figs. 18, 19).

Second, in contrast to the previous group, in this group of karbandis the corners of the base rectangle are not located on vertices of any circumferential circle;

\footnotetext{
7 Attention should be given to the fact that all of the resulted karbandis were not necessarily used in traditional architecture. Here we do not have an intention to take into account practical and other considerations of traditional architects.
} 

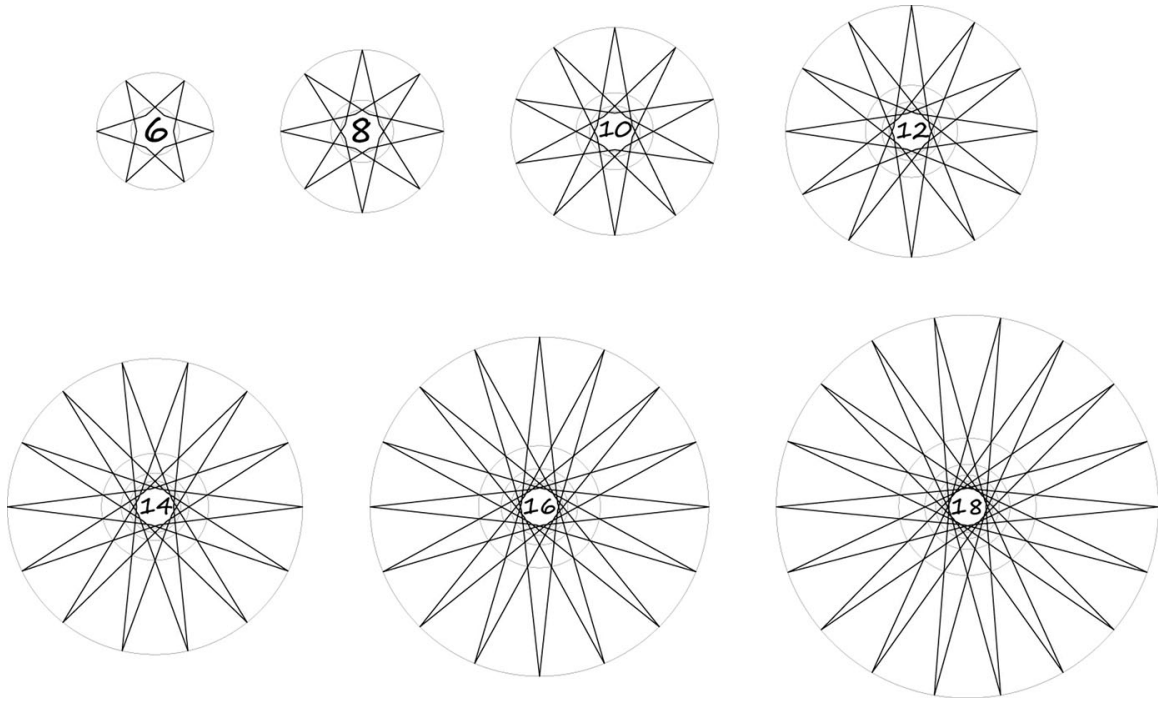

Fig. 18 Some basic stars for out of plumb karbandis
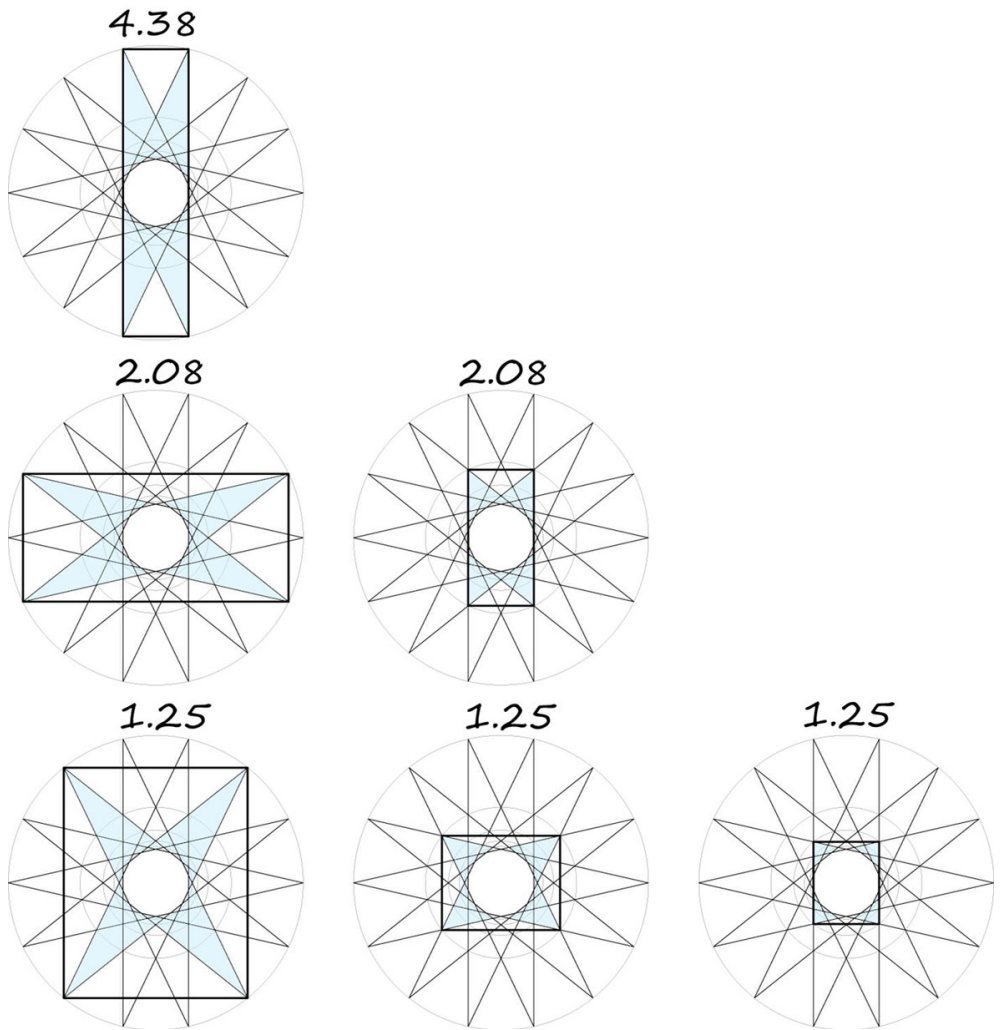

Fig. 19 One-footed karbandis produced by a basic star of 14 . The ratio of the length to width of the base rectangle is written on each example 


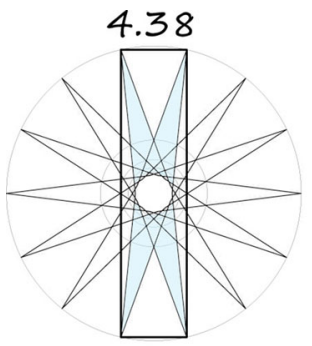

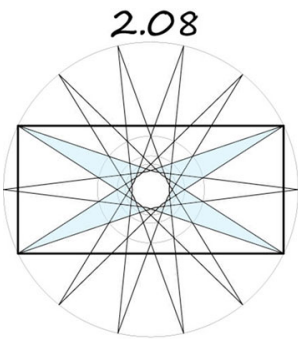

1.25

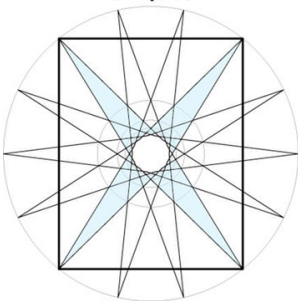

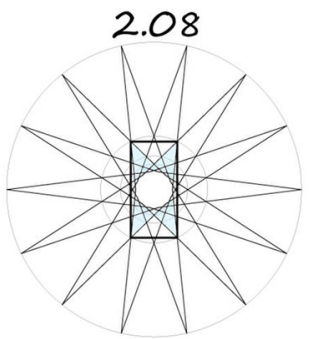

1.25

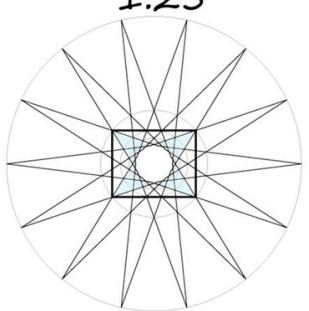

1.25

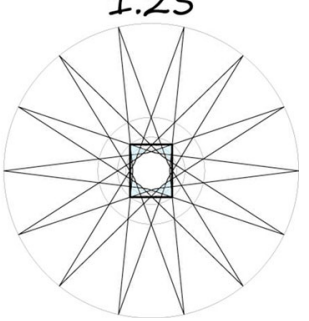

Fig. 20 Out of plumb, one-footed karbandis produced by a basic star of 14

instead there are two vertices on the sides of each corner (Figs. 21, 22). These karbandis are called two-footed in Sharbaf's method.

\section{The New Geometrical Method}

In this section a new method for classification of karbandis will be introduced step by step. In this method a set of numbers which are arranged in a specific order is used to identify and name each karbandi. Therefore, in contrast to the traditional methods, there is no need to use a long combination of difficult technical terms for this purpose.

Step 1 is the recognition of the specific basic star used in the karbandi. To do that one can simply count the number of sides of the shamseh or if it has the shape of a star-polygon, one can count the number of its wings. Note that the full shamseh is the basis for counting; for example, in nimkārs the whole shamseh should be considered, not the existing half of it. So, the first number to name a karbandi is determined.

All the three sources agree that one of the most important characteristics of a karbandi which is used in assigning a name to it is the number of sides of its 


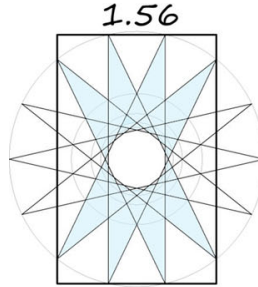

1.15

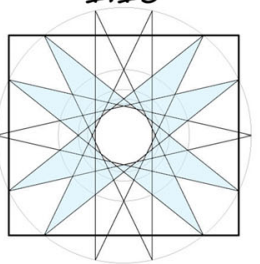

1.08

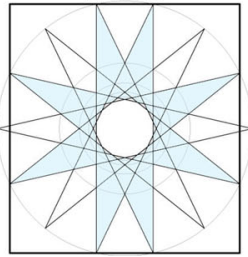

1.56

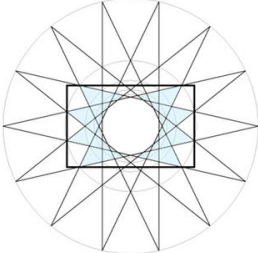

1.15

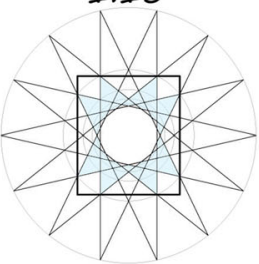

1.08

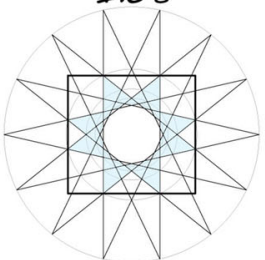

1.56

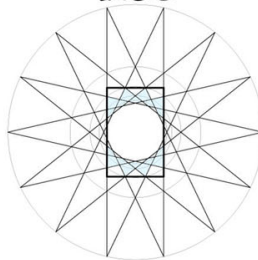

1.15

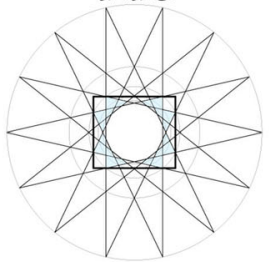

1.08

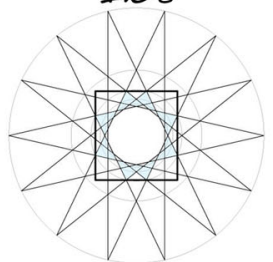

1.15

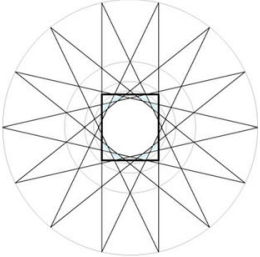

1.08

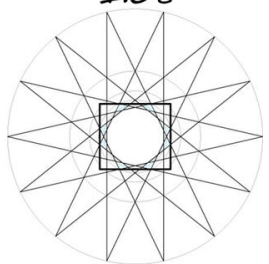

Fig. 21 Two-footed plumb karbandis produced by a basic star of 14

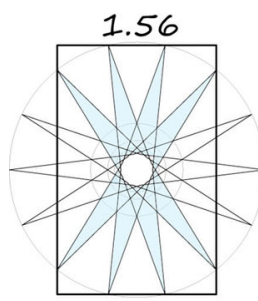

1.15

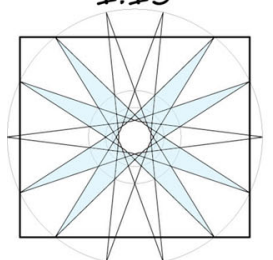

1.08

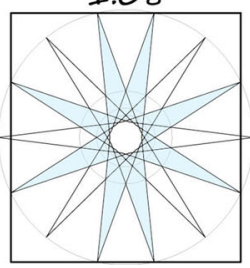

1.56

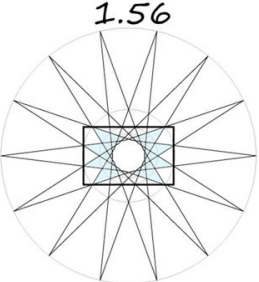

1.15

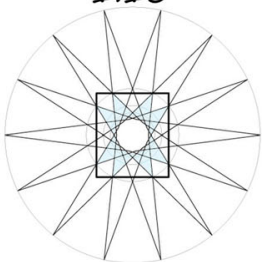

1.08

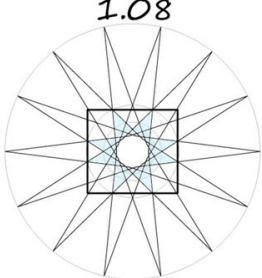

1.56

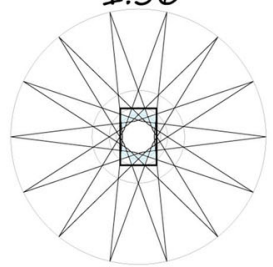

1.15

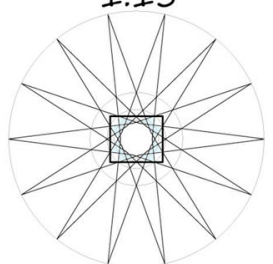

1.08

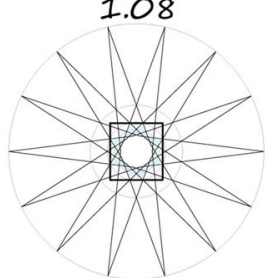

1.15

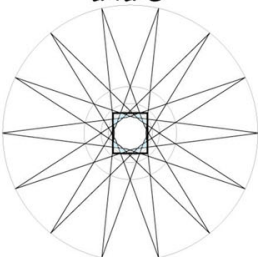

1.08

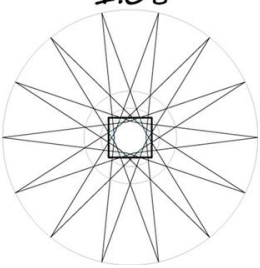

Fig. 22 Two-footed out of plumb karbandis produced by a basic star of 14 


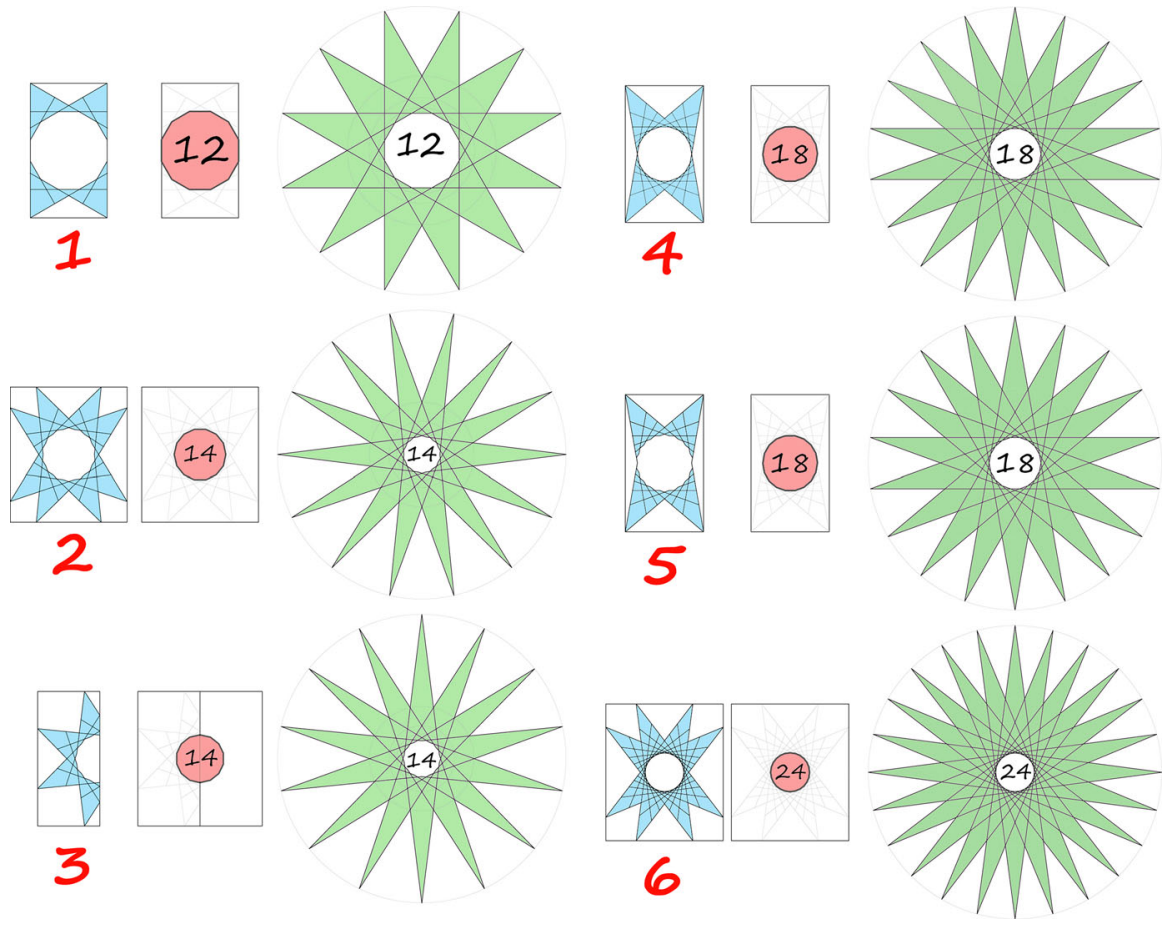

Fig. 23 Discerning the relevant basic star is the first step in identification of a karbandi

shamseh. Here we use this number to recognize the relevant basic star. In Fig. 23 six examples of karbandis are illustrated in the left column, in the middle their shamseh's number is extracted and in the right side the relevant basic star is determined and drawn.

Step 2 is in relation to whether the karbandi is a plumb kind or not. Pirnia and Sharbaf mentioned this characteristic but Lorzadeh did not. Here we define this characteristic in a simple geometrical way. Geometrical description of this characteristic refers to the horizontal angle between every two ribs that join and form a pair of ribs. This angle determines the second number in naming a karbandi.

In the horizontal plan of the karbandi if there is a $180^{\circ}$ angle between ribs of each pair of ribs, then the karbandi is a plumb kind and the number 180 is used in naming it. If the horizontal angle between the ribs of a pair is smaller than $180^{\circ}$, then the karbandi is an out of plumb kind and that exact number will be used (Fig. 24).

When looking at a real karbandi, if the observer does not have the ability to measure the exact angle, he can just discern whether the angle is $180^{\circ}$ or smaller. If it is smaller than $180^{\circ}$ then one can use the symbol " $<180^{\prime}$ " instead of the exact angle in naming the karbandi. This approach will be equivalent to Pirnia and Sharbaf's approach towards out of plumb karbandis. 


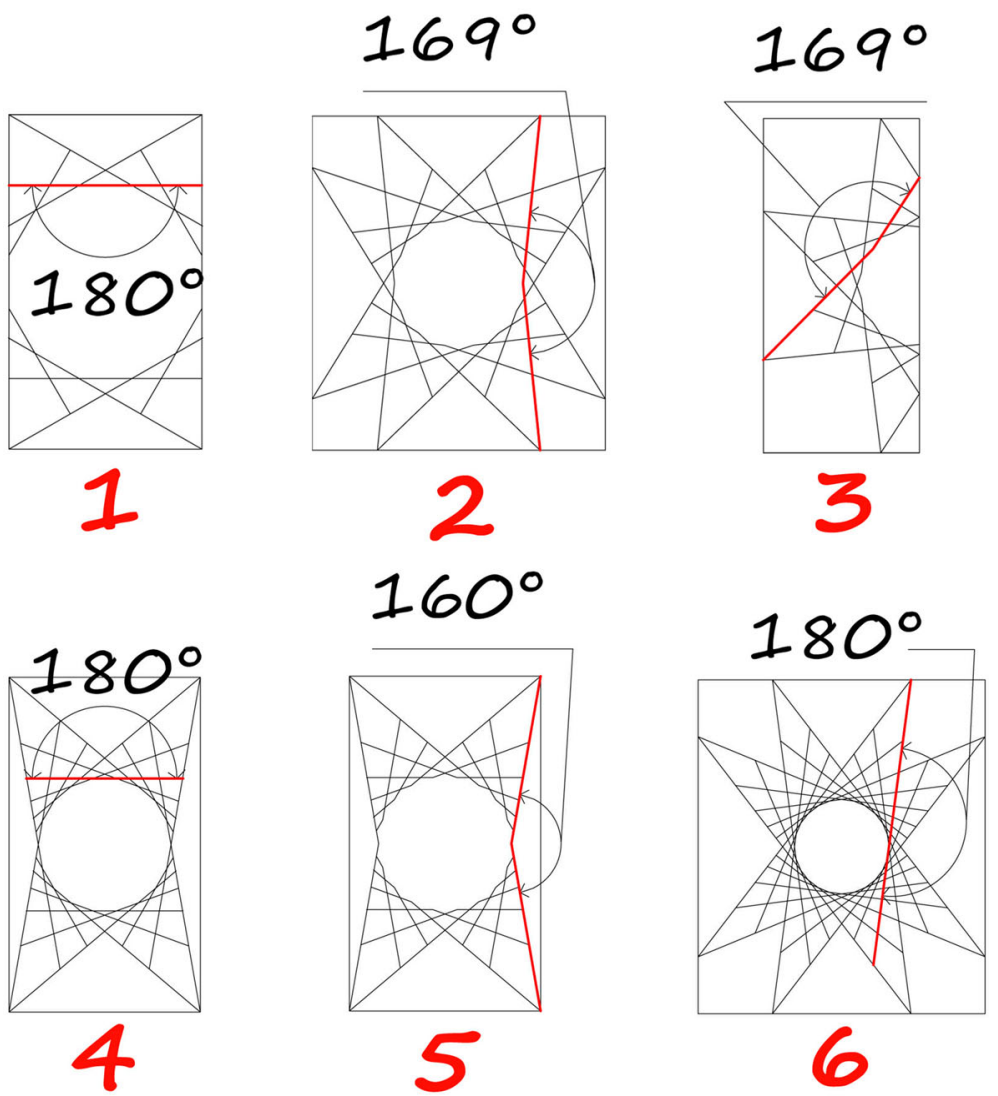

Fig. 24 Recognition of the horizontal angle in each pair of ribs

Step 3 refers to the outermost circumferential circle of the karbandi and recognizes it. We do so by counting the number of vertices of the karbandi according to this method: imagine a line that runs out of the center of the shamseh towards the outermost vertex at the end of a thin-footed cell. Then count the vertices over which this line runs. Every vertex that is formed on the intersection point of two different pair of ribs should be counted as one unit of value and the vertices that are formed at the edge of the shamseh and mark the crown of one pair of ribs will be counted as half union of value (Fig. 25).

None of the three sources mentions counting of vertices in this way. Only Pirnia has spoken of a factor that can have an equal perfomance. According to his method, in naming the stellar karbandis it should be mentioned in what order the points on the circumferential circle are connected to each other. That is to say, how many segments are between each two points that are connected. He mentions this parameter as "eight to eight" or "nine to nine" etc. in the name of the karbandi (Bozorgmehri 1992: 12-15) (Fig. 26).

The problem with his method is that the recognition of this number is very difficult when one looks at a real karbandi and tries to find the number. In addition, 

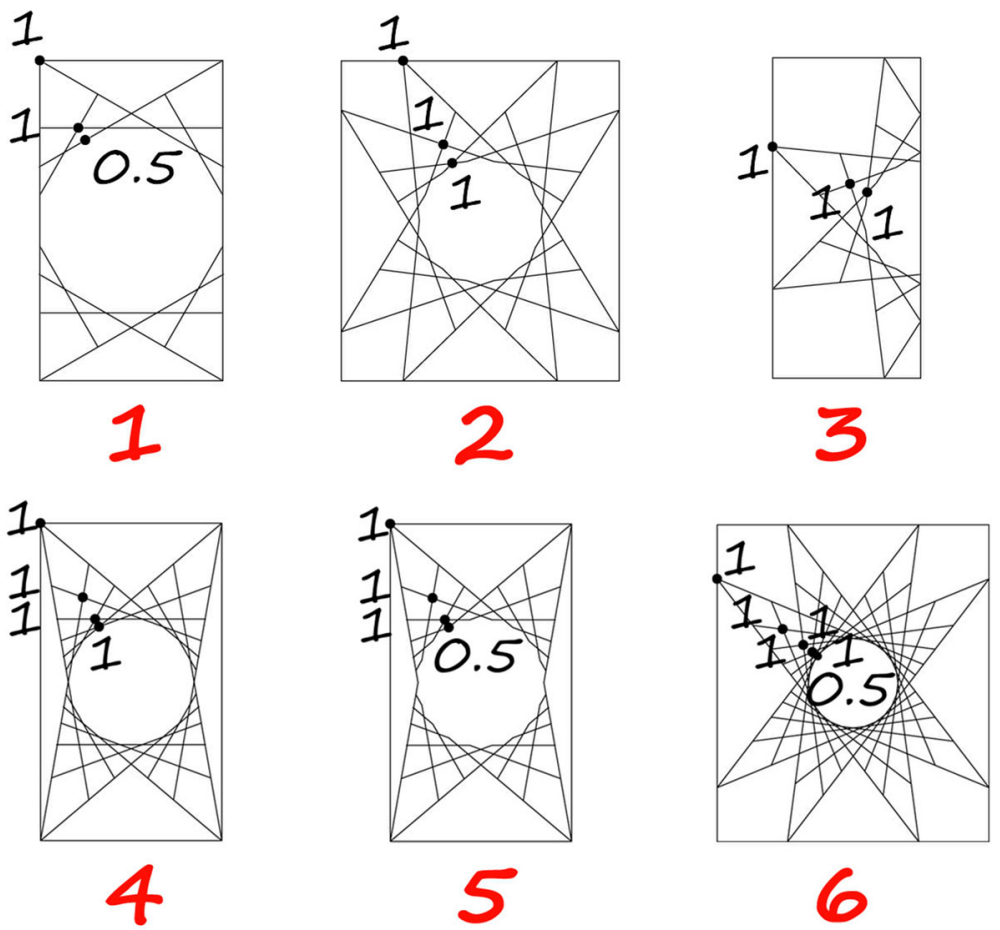

Fig. 25 Counting the number of vertices to locate the thin-footed cells

it does not define different karbandis that originate from a single basic star in a continuous geometrical relation to each other. It defines them as separate items in a segmented approach based on memorizing the samples. ${ }^{8}$

The new method solves both these difficulties. It just wants the observer to count the number of vertices as is explained here and then locate the specified karbandi on a basic star diagram conveniently (Fig. 27).

At Step 3, the third number determining the name of the karbandi is calculated. Here the identification of a karbandi is almost complete and its main features are determined, but if one wants to specify the exact shape of the base, he should continue to the next step and complete the process.

Step 4 the aim of this step is to determine the shape of the base of the karbandi. For that, one should assign a number to every vertex on the largest circumferential circle of the karbandi. The numbers should start from one at a vertex that marks the start point of a thin-footed cell and continue to increase vertex by vertex in a clockwise direction. The numbers that are assigned to vertices will be used to name the karbandi and other numbers will be discarded

\footnotetext{
8 This discrete approach to introducing karbandis is the main difficulty of Pirnia's method. Even by saying that a karbandi is an extension of another karbandi or an interlaced extension of two other karbandis the complicatedness of the problem is not reduced.
} 


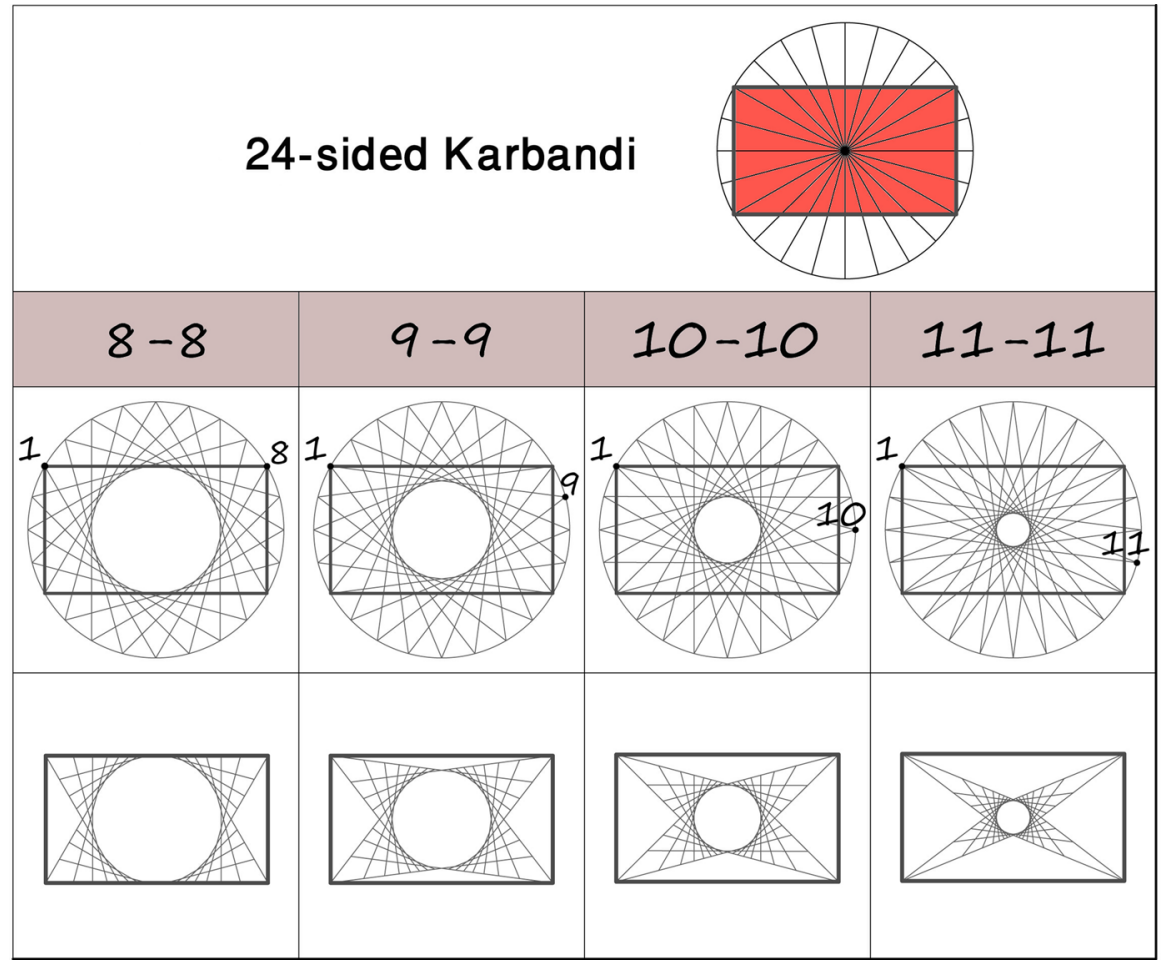

Fig. 26 In Pirnia's method for stellar karbandis, the order in which the vertices on the circumferential circle are connected is mentioned

(Fig. 28). The numbers corresponding to thin-footed cells are written in a serial order starting from one.

At the 4th step the recognition of the main characteristics of the karbandi is complete. Now the acquired numbers should be arranged in a proper form. The author suggests that they be arranged in a fraction whose numerator consists respectively of the number of the basic star, the horizontal angle between joined ribs at the shamseh's border, and the number of the vertices at the axe of thinfooted cells. At the denominator of the fraction the numbers of the vertices used in the start point of thin-footed cells of the karbandi will be written in a numerical order. And finally, by using these sets of numbers one can identify a given karbandi (Fig. 29).

\section{Some Practical Examples}

Having explained the new method, in this section some practical examples are presented to better demonstrate the performance of this method. First, a comparison has been made between the new suggested and traditional methods of naming karbandis on two examples of karbandis: one from Pirnia's book and another from 


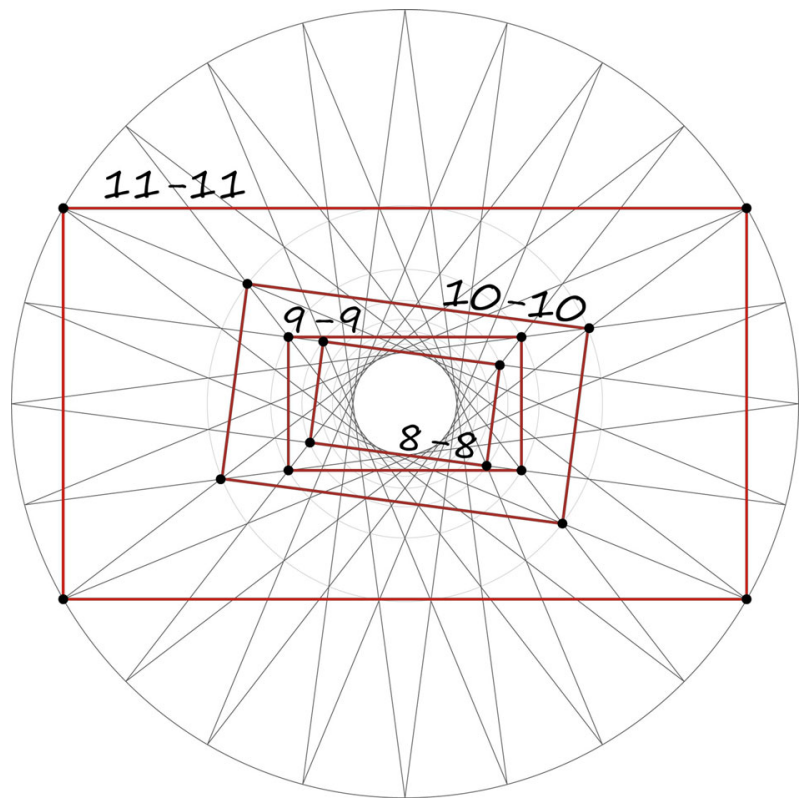

Fig. 27 Pirnia uses a complicated and discrete method to define these karbandis, while the idea of using basic stars places them on a single continuum and suggests a much simpler solution

Sharbaf's. The relative simplicity of the new method can be considered by this comparison. Next, using the photo of a real karbandi, it is demonstrated that how one can find its name.

Example 1 The name of the karbandi illustrated in Fig. 30 as it is defined in Pirnia's method (Bozorgmehri 1992: 81) is: An extension of twenty-sided karbandi on a base of eight, a discrete stellar type of five to five. While the name of this karbandi according to the method defined in this paper is:

$$
\frac{20,162^{\circ}, 2.5}{2(1,3,6,8)}
$$

Example 2 The name of the karbandi in Fig. 31 as it is defined in Sharbaf's method (Pour Nāderi 1999: 154) is: Out of plumb rasmi of 24 in a base of small and large six. ${ }^{9}$ While the name of this karbandi according to the method defined in this paper is:

$$
\frac{24,120^{\circ}, 3.5}{1,6,11,13,18,23}
$$

Example 3 Now it is time to return to the primary concern that initiated this research: how can one name a real Persian karbandi by looking at it? Suppose that somebody is visiting the mosque in Fig. 32 and looks at this iwan. How can he

\footnotetext{
${ }^{9}$ Shish-e koochak va bozorg (in Farsi): the name for a certain type of hexagon.
} 


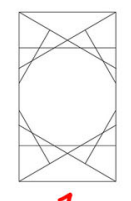

1
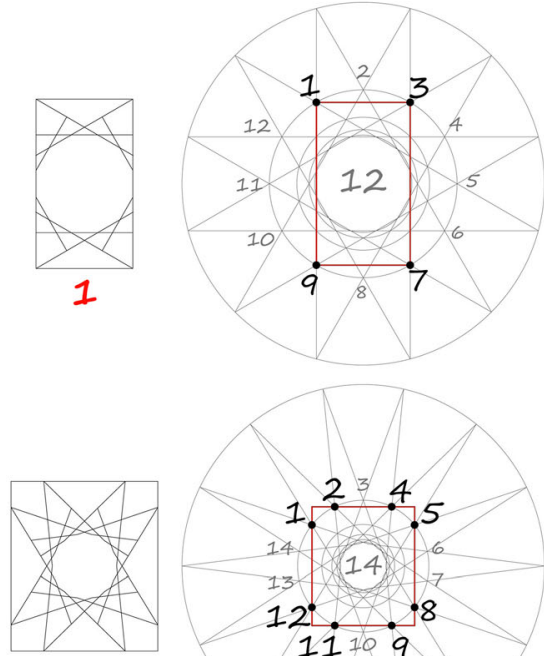

2
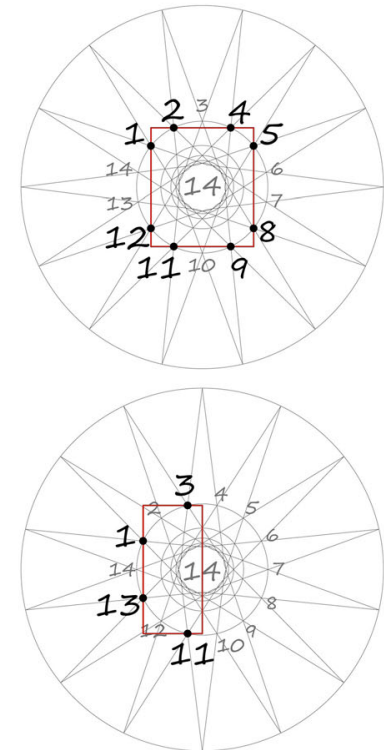

3

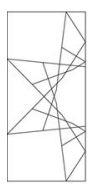

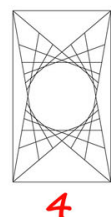
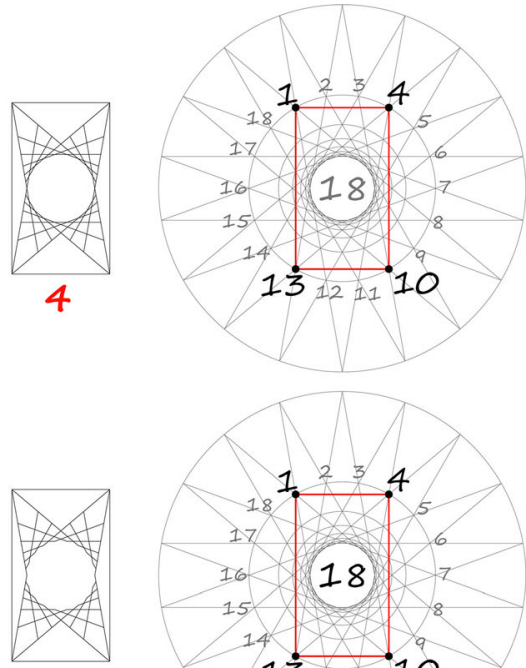

5

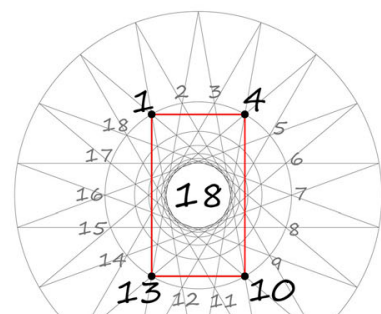

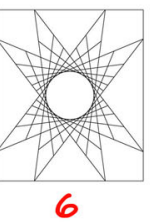

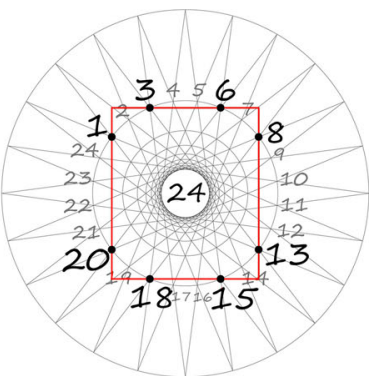

Fig. 28 Specifying the outline of the base

identify and name the karbandi which is there by using the new geometrical method?

To name this karbandi, first, one should count the number of the sides of the shamseh and determine its basic star. Here 12 toranjs (etrog citrons) surround the shamseh and as it is a nimkār (semi-work) karbandi, therefore the basic star is 24-sided (Fig. 33).

The next job is to determine whether the horizontal angle at the crown of the ribs is $180^{\circ}$ or smaller. To do that, one solution is that one looks to an uppermost located toranj. ${ }^{10}$ If its two upper sides can be located in one vertical flat surface, then the pre-mentioned angle will be $180^{\circ}$ (Fig. 34). Otherwise, it is smaller than that. Note that the upper sides of all other toranjs in lower rows always incline toward the center of the shamseh and their angle is smaller than $180^{\circ}$.

\footnotetext{
${ }_{10}$ These toranjs may be called by some traditional architects "shaparak" which means "butterfly".
} 


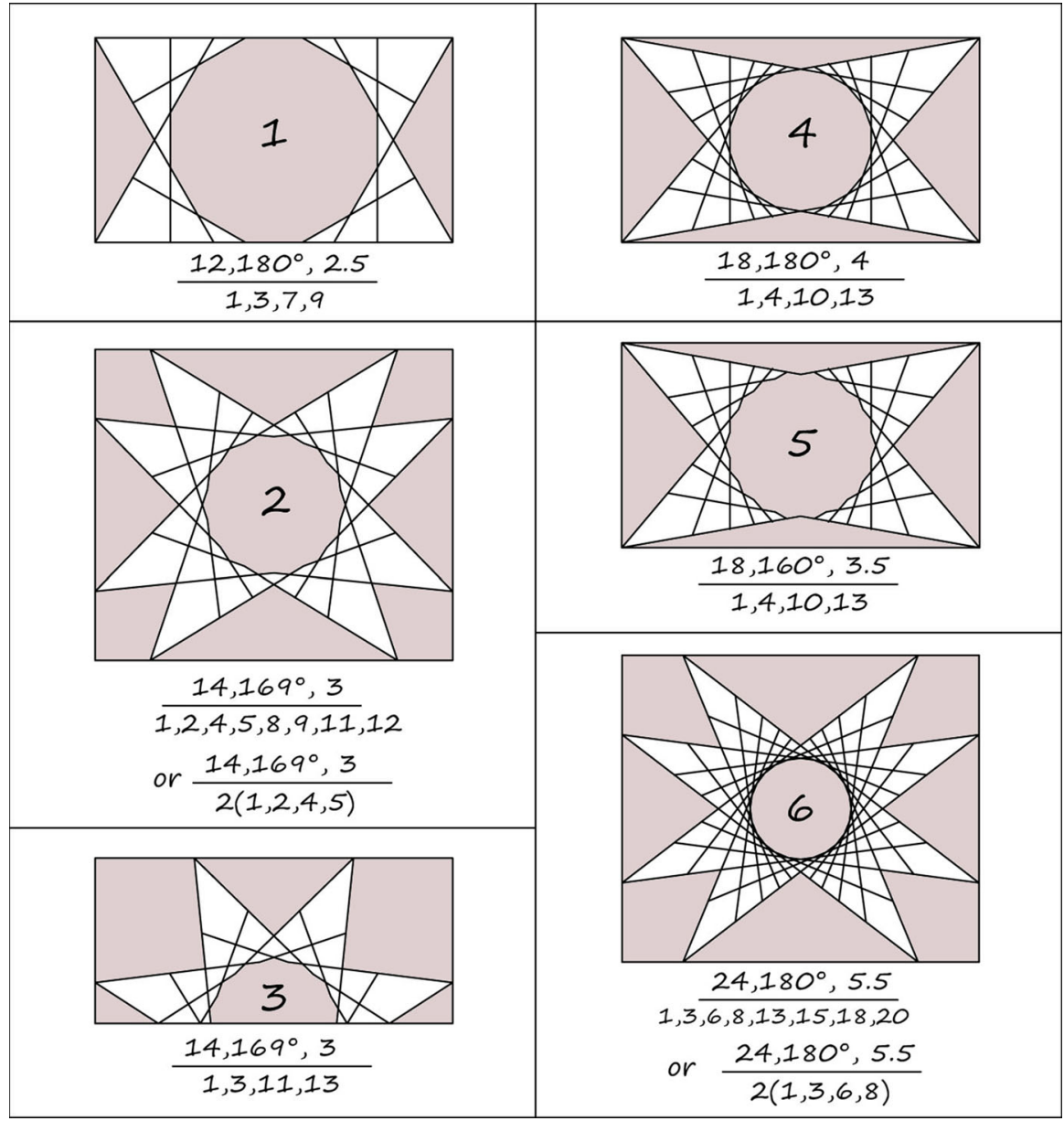

Fig. 29 Names specified for sample karbandis according to the new naming system

In the given karbandi, if we look at a toranj which is adjacent to the shamseh (Fig. 35), it is observed that the two upper sides are not in a vertical surface; rather they are inclined toward the center of the shamseh. So, the angle is smaller than $180^{\circ}$. Of course, one cannot measure the exact amount of the angle without the necessary tools and measures. Here one may just use the symbol " $<180^{\circ}$ " to indicate the condition.

Now the number of vertices should be determined. To do that one should start from the rising point of a thin-footed cell and count the number of vertices to the edge of the shamseh. Here the result is 3 (Fig. 36).

Finally, the outline of the base is extracted. To this end, one should locate the thin-footed cells on a sample diagram of a basic star of 24 and complete the shape of the base then assign numbers to the vertices. These are illustrated in Fig. 37. 

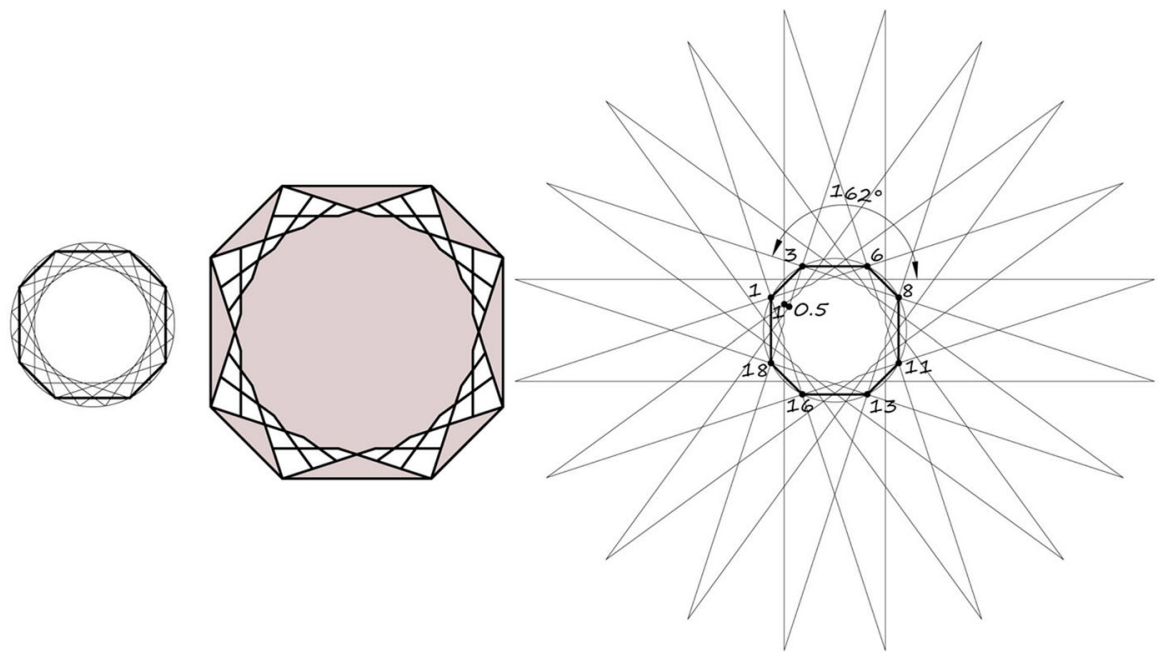

Fig. 30 The name of a karbandi in Pirnia's method and in the new geometrical method
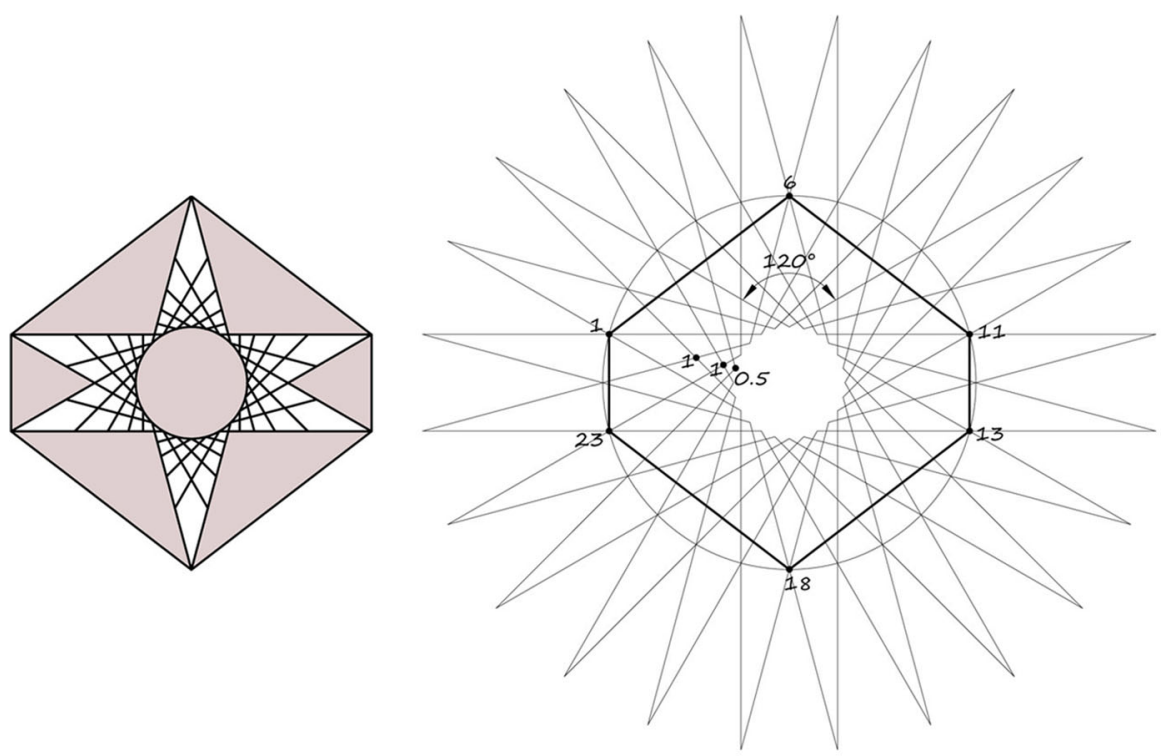

Fig. 31 The name of a karbandi in Sharbaf's method and in the new geometrical method

Therefore the name of the karbandi will be like this:

$$
\frac{24,<180^{\circ}, 3}{1,3,7,9}
$$




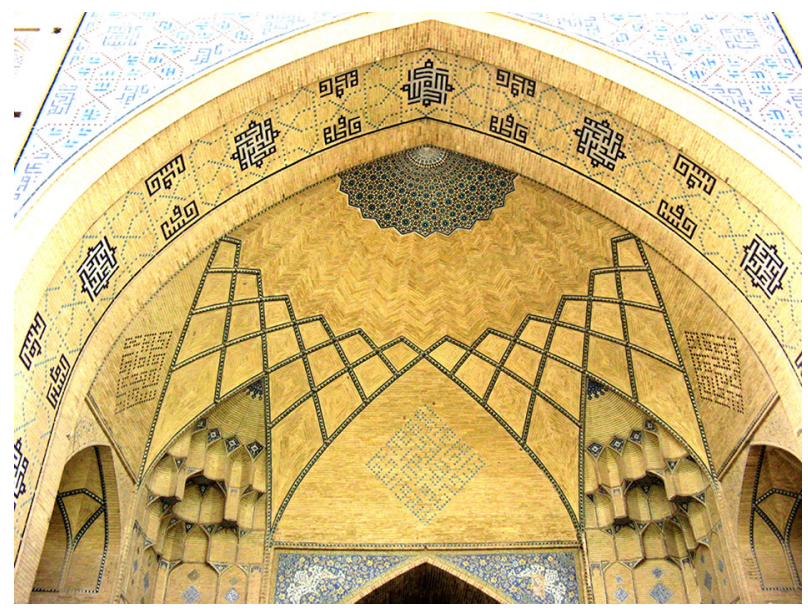

Fig. 32 How can the visitor of this building identify this karbandi using the new method?

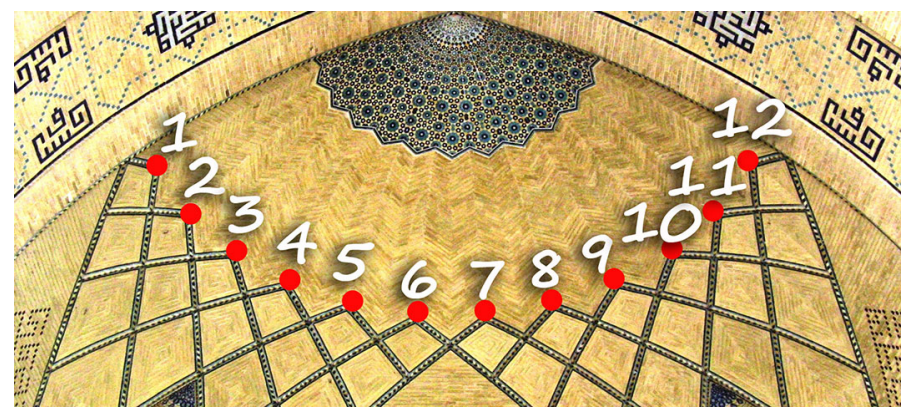

Fig. 33 This is a 24-sided nimkar

Fig. 34 Left an example of toranjs with a $180^{\circ}$ horizontal angle. The rib "abc" is plumb. Bazar, Isfahan

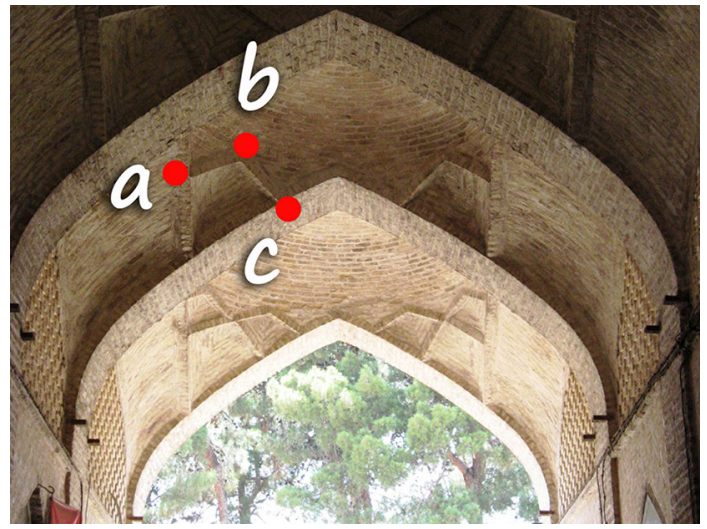


Fig. 35 Right the rib segment "abc" is inclined towards the center and is out of plumb
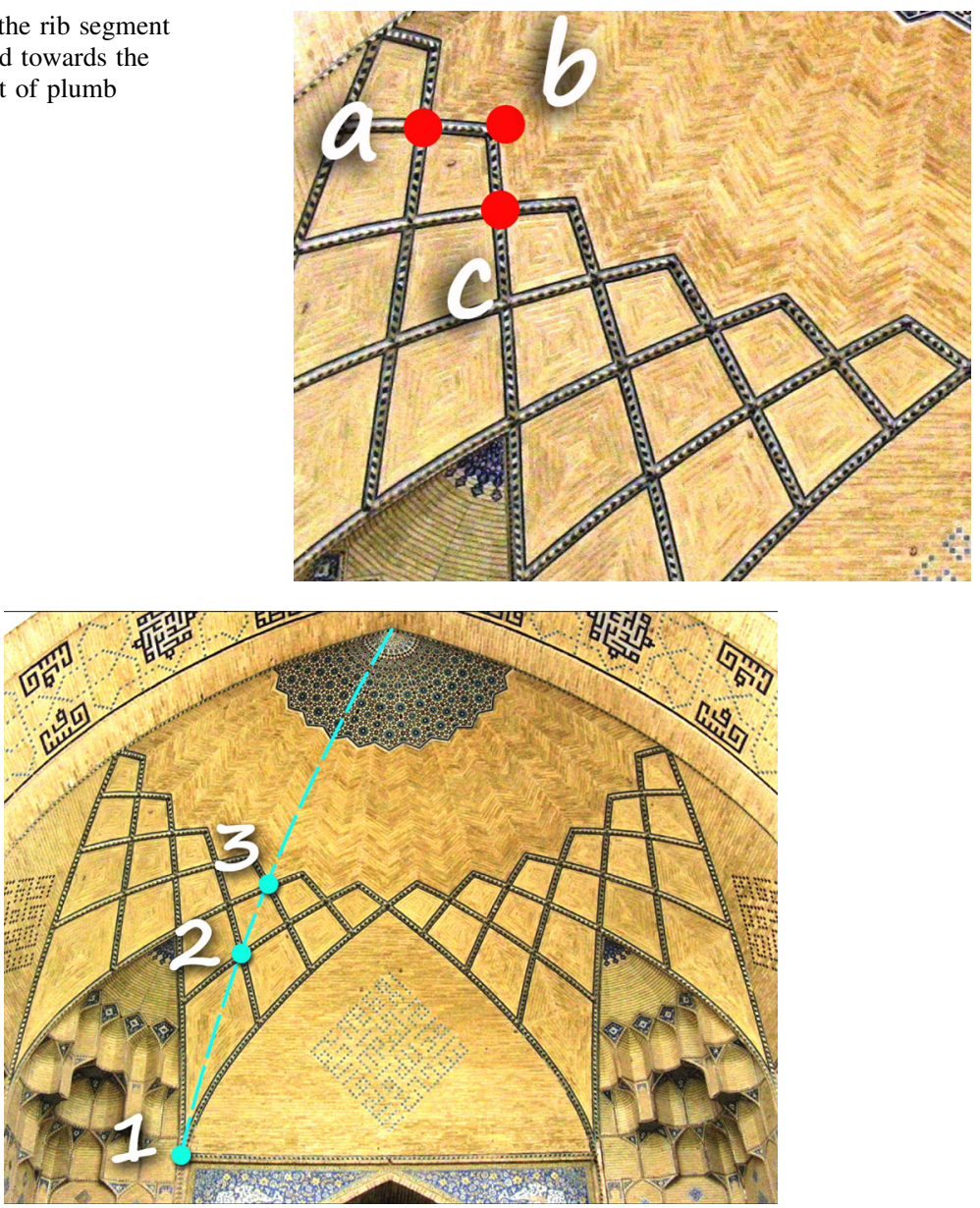

Fig. 36 Counting the number of vertices

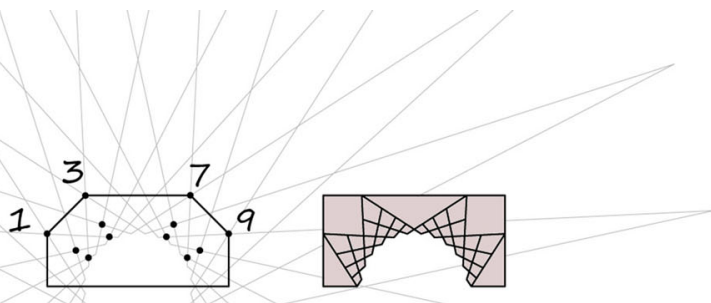

Fig. 37 Locating the vertices on the sample basic star diagram 


\section{Conclusion}

In this paper a new geometrical method for naming karbandis was presented in response to the problem that was observed in this respect. The author believes that by using this geometrical method one can more easily identify and name karbandis when studying Persian architecture and especially when visiting its works on site. It helps to standardize the method of identifying karbandis and resolves some difficulties arising from scattered traditional methods.

For the time being, this geometrical approach can be considered as a complementary method along with traditional methods to streamline our understanding of karbandis. In fact, it only concentrates on the main characteristics of karbandis and more detailed and creative variations in karbandis are out of the scope of this primary method. However, by providing a new point of view towards karbandis, it may facilitate the departure from the old concept of karbandi and pave the way for a new status for it in contemporary architecture.

\section{Appendix}

In this paper the following Farsi technical words are translated/transliterated into English as follows:

\begin{tabular}{|c|c|c|c|}
\hline Farsi term & $\begin{array}{l}\text { Primary meaning } \\
\text { in Farsi }\end{array}$ & Explanation & $\begin{array}{l}\text { English translation/ } \\
\text { transliteration used } \\
\text { in this paper }\end{array}$ \\
\hline Akhtari & Stellar & A type of karbandis & Stellar \\
\hline Akhtari-ye gosasteh & Discrete stellar & A type of karbandis & Discrete stellar \\
\hline Akhtari-ye peyvasteh & Continuous stellar & A type of karbandis & Continuous stellar \\
\hline Ālat & Piece, cell & $\begin{array}{l}\text { Each of the pieces } \\
\text { forming a karbandi }\end{array}$ & Cell \\
\hline Dar-ham & Interlaced & A type of karbandis & Interlaced \\
\hline Do-pā & Having two feet & A type of karbandis & Two-footed \\
\hline Filgoosh & Like the ear of an elephant & A type of cell & Squinch \\
\hline Filgoosh-dār & $\begin{array}{l}\text { Having filgooshes/having } \\
\text { squinches }\end{array}$ & A type of karbandis & With squinch \\
\hline Ghāleb Shāghooli & Having plumb formwork & A type of karbandis & Plumb \\
\hline Ghāleb Sar Seft & Having thrusting-headed formwork & A type of karbandis & Out of plumb \\
\hline Haft/Hafti & Seven/like a seven & A type of cell & Squinch \\
\hline Hasht & Eight & A regular octagon & Eight \\
\hline Hasht va nim-hasht & Eight and Half-eight & A type of octagon & Eight and Half-eight \\
\hline Kashkooli & Like the bowl of dervishes & A type of octagon & Kashkooli \\
\hline Kuneh-bandi & Fitting to ends & A type of karbandis & $\begin{array}{l}\text { End-reaching } \\
\text { karbandi }\end{array}$ \\
\hline Moshtak-shekasteh & With broken filter tip & A type of karbandis & Broken filter tip \\
\hline Negigni & Like a Ring-stone & A type of octagon & Negini \\
\hline Nim-kar & Semi-work & $\begin{array}{l}\text { A karbandi analogous } \\
\text { to half of a hemisphere }\end{array}$ & Nimkar \\
\hline
\end{tabular}


Appendix continued

\begin{tabular}{|c|c|c|c|}
\hline Farsi term & $\begin{array}{l}\text { Primary meaning } \\
\text { in Farsi }\end{array}$ & Explanation & $\begin{array}{l}\text { English translation/ } \\
\text { transliteration used } \\
\text { in this paper }\end{array}$ \\
\hline Nim-soosan & Half-lily & A type of cell & Nimsoosan \\
\hline Noghol & Deep & A type of karbandis & Deep \\
\hline Pā-bārik & Having a thin foot & A type of cell & Thin-footed \\
\hline Parvar & Repetition & A type of karbandis & Repetition \\
\hline Rasmi & Conventional & A type of karbandis & Conventional \\
\hline Shamseh & Sun-like & A type of cell & Shamseh \\
\hline Shāparak & Butterfly & A type of cell & Shāparak \\
\hline Shish-e koochak va bozorg & Small and large six & a type of hexagon & Small and large six \\
\hline Soosan/Soosani & Lily/liliaceous & A type of cell & Soosan \\
\hline Soosan-dār & Having lilies & A type of karbandis & With soosan \\
\hline Tavizeh & Rib/a pair of ribs & $\begin{array}{l}\text { Each of the arched pieces } \\
\text { forming the structure } \\
\text { of a karbandi }\end{array}$ & Rib/a pair of ribs \\
\hline Tonok & Shallow & A type of karbandis & Shallow \\
\hline Toranj & Etrog citron & A type of cell & Toranj \\
\hline Yek-pā & Having one foot & A type of karbandis & One-footed \\
\hline Zamineh & Base & $\begin{array}{l}\text { The base on which a } \\
\text { karbandi is erected }\end{array}$ & Base \\
\hline
\end{tabular}

\section{References}

Bozorgmehri, Z. 1992. Hendese Dar Me'māri (Geometry in Architecture). Tehran: Sāzmān-e Mirās-e Farhangi-ye Keshvar (Iranian Cultural Heritage Organization). (In Farsi).

Fuentes, P., and S. Huerta. 2010. Islamic domes of crossed-arches: Origin, geometry and structural behavior. ARCH'10 -6th international conference on arch bridges. Fuzhou. http://www.archbridges.cn/paper2010/html/paper4.html. Accessed 24 May 2013.

Necipoglu, G. 1995. The Topkapi scroll: geometry and ornament in islamic architecture. with an essay on the geometry of the Muqarnas By Mohammad Al-Asad. Santa Monica: The Getty Center for the History of Art and the Humanities.

Pour Nāderi, H. 1999. Sha'rbāf Va Āsārash (Jeld-E Dovvom-E Gereh Va Karbandi) (Sharbaf and his works: second volume of Gereh And Karbandi). Tehran: Sāzmān-e Mirās-e Farhangi-ye Keshvar (Iranian Cultural Heritage Organization). (In Farsi).

Ra'ees Zādeh, M., and H. Mofid. 2011. Ehyā-ye Honar Hā-ye Az Yād Rafteh: Mabāni-ye Me'māri-ye Sonnati Dar Iran Be Revāyat-e Ostād Hossein-e Lorzādeh (Revival Of Forgotten Arts: Basics Of Traditional Architecture In Iran As Narrated By Master Hossein-E Lorzadeh). Tehran: Enteshārāt-e Moulā (Moula Publications). (in Farsi).

Sha'rbāf, A. 2006. Gereh va Karbandi (Gereh and Karbandi). Tehran: Sāzmān-e Mirās-e Farhangi-ye Keshvar (Iranian Cultural Heritage Organization). (in Farsi).

Mojtaba Pour Ahmadi is a lecturer at the University of Guilan. He received his M.Sc. in architecture from the University of Tehran in 2006 and since 2012 has been completing a Ph.D. program in architecture at Iran University of Science and Technology. His thesis is related to the quality control of architectural designs and its methodology. He is also interested in studying the relationship between architecture and mathematics and has published papers on this subject. 